Prepared in cooperation with the U.S. Environmental Protection Agency

\title{
Spring Runoff Water-Chemistry Data for the Standard Mine and Elk Creek, Gunnison County, Colorado, 2010
}

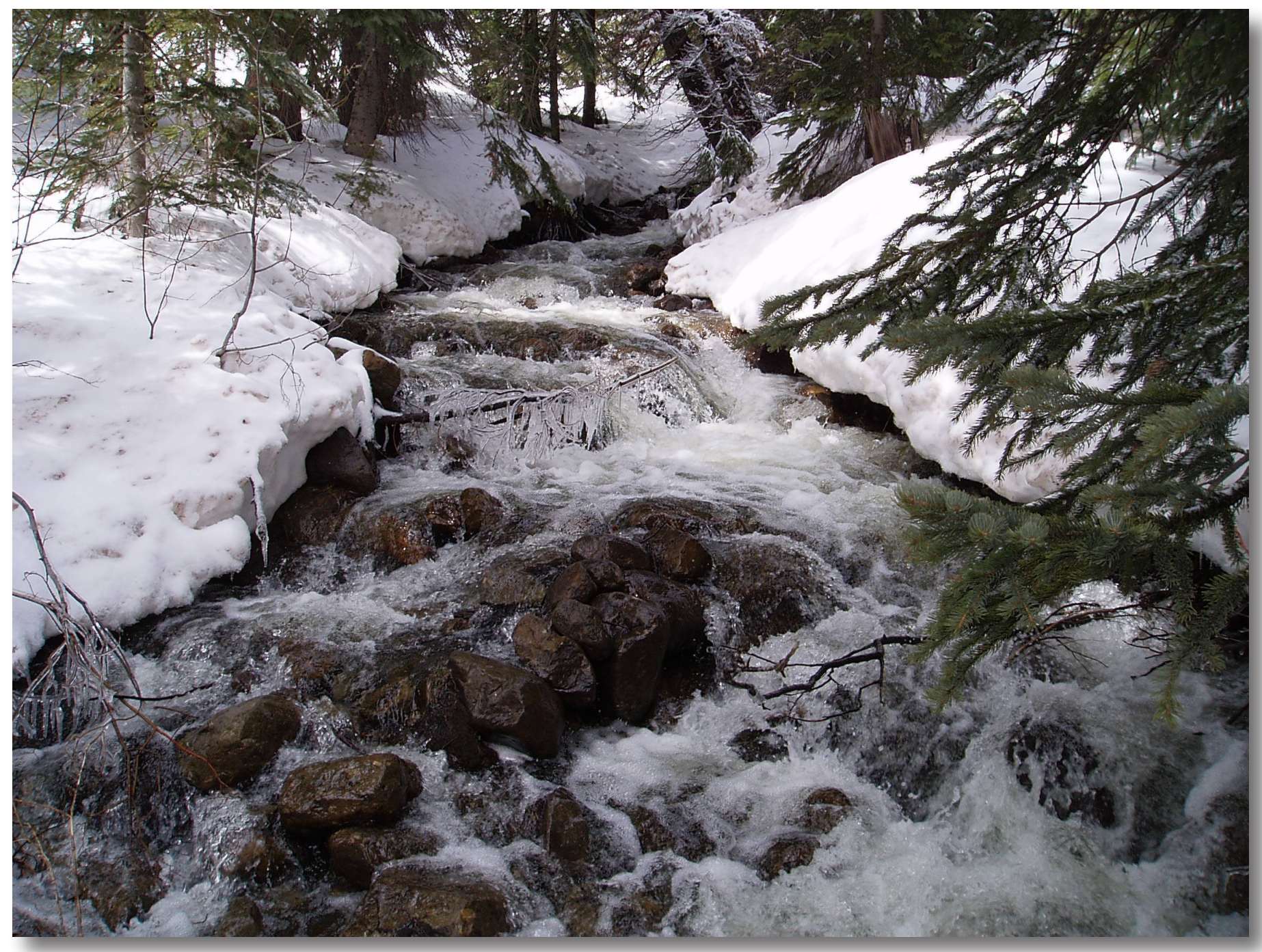

Open-File Report 2011-1159 



\section{Spring Runoff Water-Chemistry Data from the Standard Mine and Elk Creek, Gunnison County, Colorado, 2010}

By Andrew H. Manning, Philip L. Verplanck, M. Alisa Mast, Joseph Marsik, and

R. Blaine McCleskey

Prepared in cooperation with the U.S. Environmental Protection Agency

Open-File Report 2011-1159 


\section{U.S. Department of the Interior \\ KEN SALAZAR, Secretary \\ U.S. Geological Survey \\ Marcia K. McNutt, Director}

\section{U.S. Geological Survey, Reston, Virginia: 2011}

For product and ordering information:

World Wide Web: http://www.usgs.gov/pubprod

Telephone: 1-888-ASK-USGS

For more information on the USGS—-the Federal source for science about the Earth, its natural and living resources, natural hazards, and the environment:

World Wide Web: http://www.usgs.gov

Telephone: 1-888-ASK-USGS

Suggested citation:

Manning, A.H., Verplanck, P.L., Mast, M.A., Marsik, Joseph, and McCleskey, R.B., 2011, Spring runoff water-chemistry data from the Standard Mine and Elk Creek, Gunnison County, Colorado, 2010: U.S. Geological Survey Open-File Report 2011-1159, 20 p.

Any use of trade, product, or firm names is for descriptive purposes only and does not imply endorsement by the U.S. Government.

Although this report is in the public domain, permission must be secured from the individual copyright owners to reproduce any copyrighted material contained within this report. 


\section{Contents}

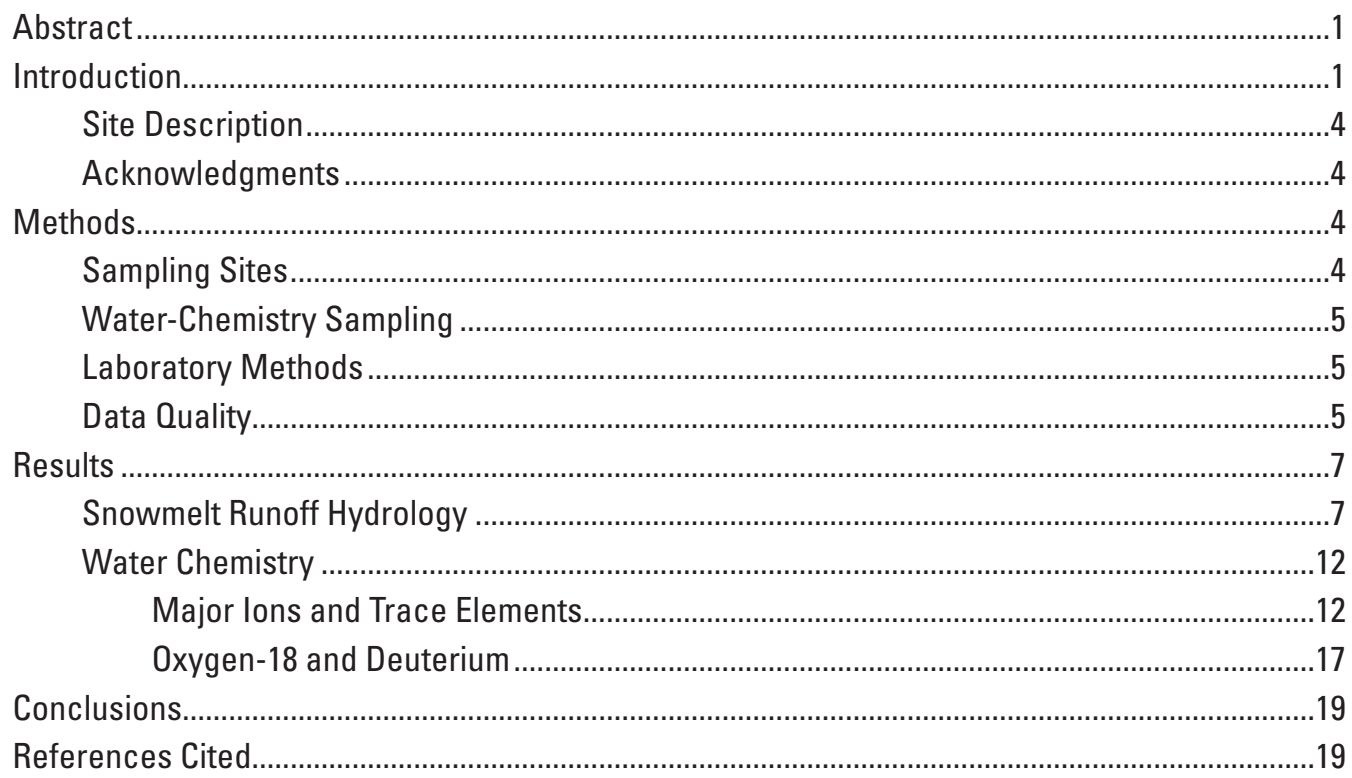

\section{Figures}

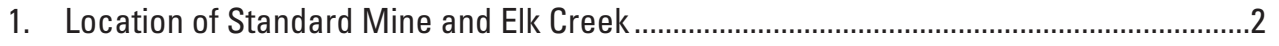

2. Location of sample sites............................................................................................

3. Comparison of analytical results by using ICP-MS (inductively coupled plasma-mass spectrometry) and ICP-AES (inductively coupled plasma-atomic emission spectroscopy)

4. Snow water equivalent data from Schofield Pass snow telemetry site (A) and streamflow data from the East River near the town of Crested Butte (B) for the years 2007 and 2010 compared to mean values.

5. Streamflow records for the Level 1 portal, ELK-00 gage, and the USGS East River gage for the spring of 2010. Snow water equivalent (SWE) measured at the Schofield Pass snow telemetry site is also shown

6. Photographs showing snowpack at the Level 1 portal on the six sampling days (A through F) during the spring of 2010

7. Photographs showing flow in Elk Creek on the six sampling days (A through F) during the spring of 2010

8. Box-and-whisker plots comparing 2007 and 2010 measurements at sample site EC-MSTD1 (A) and sample site EC-CELK1 (B)............................................................13

9. $\mathrm{pH}(\mathrm{A})$ and specific conductance (B) plotted versus sample date..................................14

10. Calcium $(A)$ and sulfate $(B)$ concentration plotted versus sample date.........................14

11. Zinc (A), cadmium (B), manganese (C), lead (D), and copper (E) concentration plotted versus sample date. Only samples with concentrations above detection limit are shown.

12. Bar charts showing calculated loads for zinc (A), cadmium (B), manganese (C), lead (D), and copper (E) .......................................................................................

13. $\delta^{18} O(\mathrm{~A})$ and $\delta^{2} \mathrm{H}(\mathrm{B})$ values plotted versus calendar day of sample collection...............18 


\section{Tables}

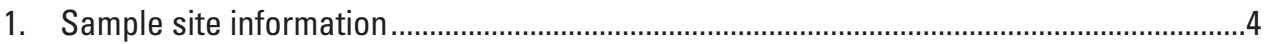

2. Methods of analysis and detection limits ..........................................................................

3. Concentrations of major ions and selected metals ..................................................... link

4. Results of inductively coupled plasma-mass spectrometry (ICP-MS) analyses .......... link

5. Oxygen-18 and deuterium results ................................................................................. 17

\section{Conversion Factors}

Inch/Pound to SI

\begin{tabular}{lll}
\hline \multicolumn{1}{c}{ Multiply } & \multicolumn{1}{c}{ By } & \multicolumn{1}{c}{ To obtain } \\
\hline inch (in) & Length & \\
foot (ft) & 2.54 & centimeter $(\mathrm{cm})$ \\
mile (mi) & 0.3048 & meter $(\mathrm{m})$ \\
\hline \multicolumn{3}{c}{ Area } \\
\hline square mile $\left(\mathrm{mi}^{2}\right)$ & 1.609 & kilometer $(\mathrm{km})$ \\
Flow rate & 2.590 & square kilometer $\left(\mathrm{km}^{2}\right)$ \\
cubic foot per second $(\mathrm{cfs})$ & & \\
\hline
\end{tabular}

Temperature in degrees Celsius $\left({ }^{\circ} \mathrm{C}\right)$ may be converted to degrees Fahrenheit $\left({ }^{\circ} \mathrm{F}\right)$ as follows:

${ }^{\circ} \mathrm{F}=\left(1.8 \times{ }^{\circ} \mathrm{C}\right)+32$

Vertical coordinate information is referenced to the North American Vertical Datum of 1988 (NAVD 88).

Horizontal coordinate information is referenced to the North American Datum of 1983 (NAD 83).

Altitude, as used in this report, refers to distance above the vertical datum.

Specific conductance is given in microsiemens per centimeter at 25 degrees Celsius $(\mu \mathrm{S} / \mathrm{cm}$ at $\left.25^{\circ} \mathrm{C}\right)$.

Concentrations of chemical constituents in water are given either in milligrams per liter (mg/L) or micrograms per liter ( $\mu \mathrm{g} / \mathrm{L})$. 


\title{
Spring Runoff Water-Chemistry Data from the Standard Mine and Elk Creek, Gunnison County, Colorado, 2010
}

\author{
By Andrew H. Manning, Philip L. Verplanck, M. Alisa Mast, Joseph Marsik, and R. Blaine McCleskey
}

\section{Abstract}

Water samples were collected approximately every two weeks during the spring of 2010 from the Level 1 portal of the Standard Mine and from two locations on Elk Creek. The objective of the sampling was to: (1) better define the expected range and timing of variations in $\mathrm{pH}$ and metal concentrations in Level 1 discharge and Elk Creek during spring runoff; and (2) further evaluate possible mechanisms controlling water quality during spring runoff. Samples were analyzed for major ions, selected trace elements, and stable isotopes of oxygen and hydrogen (oxygen-18 and deuterium). The Level 1 portal sample and one of the Elk Creek samples (EC-CELK1) were collected from the same locations as samples taken in the spring of 2007, allowing comparison between the two different years. Available meteorological and hydrologic data suggest that 2010 was an average water year and 2007 was below average.

Field $\mathrm{pH}$ and dissolved metal concentrations in Level 1 discharge had the following ranges: $\mathrm{pH}, 2.90$ to 6.23 ; zinc, 11.2 to $26.5 \mathrm{mg} / \mathrm{L}$; cadmium, 0.084 to $0.158 \mathrm{mg} / \mathrm{L}$; manganese, 3.23 to $10.2 \mathrm{mg} / \mathrm{L}$; lead, 0.0794 to $1.71 \mathrm{mg} / \mathrm{L}$; and copper, 0.0674 to $1.14 \mathrm{mg} / \mathrm{L}$. These ranges were generally similar to those observed in 2007. Metal concentrations near the mouth of Elk Creek (EC-CELK1) were substantially lower than in 2007. Possible explanations include remedial efforts at the Standard Mine site implemented after 2007 and greater dilution due to higher Elk Creek flows in 2010. Temporal patterns in $\mathrm{pH}$ and metal concentrations in Level 1 discharge were similar to those observed in 2007, with $\mathrm{pH}$, zinc, cadmium, and manganese concentrations generally decreasing, and lead and copper generally increasing during the snowmelt runoff period. Zinc and cadmium concentrations were inversely correlated with flow and thus apparently dilution-controlled. Lead and copper concentrations were inversely correlated with $\mathrm{pH}$ and thus apparently $\mathrm{pH}$-controlled. Zinc, cadmium, and manganese concentrations near the mouth of Elk Creek did not display the pronounced increase observed during high flow in 2007, again perhaps due to remedial activities at the mine site or greater dilution in 2010.

Zinc and cadmium loads near the mouth of Elk Creek were generally greater than those at the Level 1 portal for the six sample days in 2010. Whereas metal loads in September
2007 suggested that Level 1 portal discharge was the primary source of metals to the creek, metal loads computed for this study suggest that this may not have been the case in the spring of 2010. $\delta^{18} \mathrm{O}$ values are well correlated with flow, becoming lighter (more negative) during snowmelt in both Level 1 discharge and Elk Creek. Seasonal variations in the chemistry of Level 1 discharge, along with portal flow tracking very closely with creek flow, are consistent with geochemical and environmental tracer data from 2007 that indicate short residence times ( $<1$ year) for groundwater discharging from the Standard Mine.

\section{Introduction}

In 2006, the U.S. Environmental Protection Agency (USEPA) listed the Standard Mine in the Elk Creek watershed near Crested Butte, Colorado (fig. 1), as a Superfund Site. Drainage from the Standard Mine enters Elk Creek, contributing dissolved and suspended loads of zinc, cadmium, copper, and other metals to the stream. Elk Creek flows into Coal Creek, which is a source of drinking water for the town of Crested Butte. This study is the latest in a series of studies performed by the U.S. Geological Survey (USGS) since 2006 to characterize the geology, hydrogeology, and water chemistry in the vicinity of the Standard Mine and assist the USEPA in evaluating remedial options for the site (Verplanck and others, 2007; Manning and others, 2008; Caine and others, 2010; Minsley and others, 2010; Verplanck and others, 2010).

The purpose of this report is to provide additional data to: (1) better define the expected range and timing of variations in $\mathrm{pH}$ and metal concentrations in Level 1 portal discharge and Elk Creek during spring runoff; and (2) further evaluate possible mechanisms controlling water quality during spring runoff. Water-chemistry samples were collected from the Level 1 portal of the Standard Mine (EC-MSTD1) and two locations on Elk Creek during the spring of 2010 (fig. 2). The two Elk Creek locations include EC-CELK1 located just above the confluence with Coal Creek, and EC-CELK2 located approximately one-third of the distance downstream from EC-MSTD1 to EC-CELK1 (close to USEPA sample site ELK-08). Samples were collected approximately every two weeks during the snowmelt runoff period in April, May, and June, 2010. 


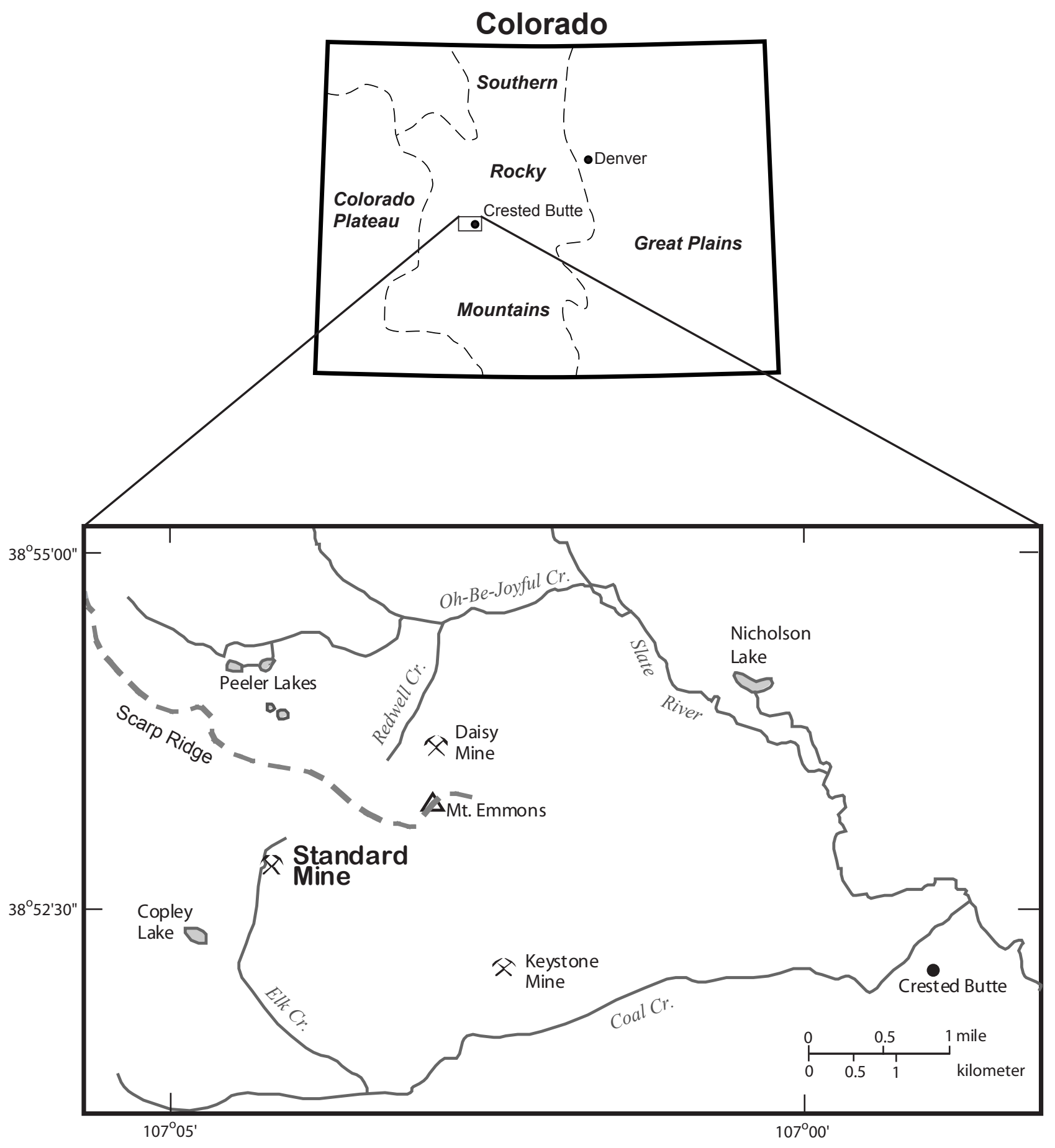

Figure 1. Location of Standard Mine and Elk Creek. 


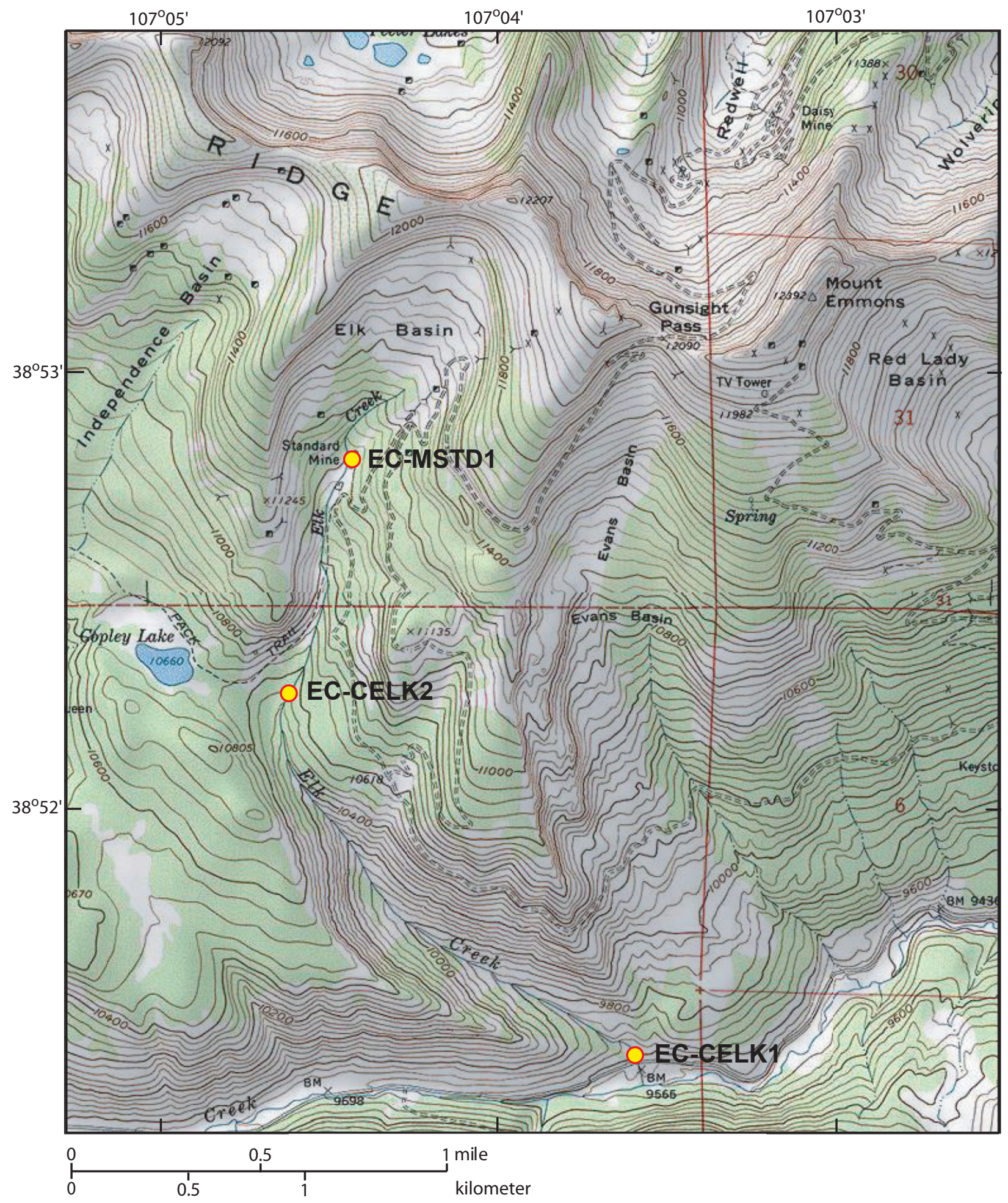

Figure 2. Location of sample sites. Base map compiled from U.S. Geological Survey 1:24,000 topographic maps of the Oh-Be-Joyful, Colo. and Mt Axtell, Colo. quadrangles (1973). Contour interval, 40 feet. 
Samples were analyzed for $\mathrm{pH}$ and specific conductance, as well as concentrations of major ions, selected trace elements, and stable isotopes of oxygen and hydrogen (oxygen-18 and deuterium). Five samples were collected by the USGS from EC-MSTD1 and EC-CELK1 during the same period in 2007 and analyzed for the same water quality constituents (Manning and others, 2008).

\section{Site Description}

The Standard Mine is located within the Elk Creek watershed, a roughly 2-square mile subalpine to alpine watershed located approximately 4 miles (mi) west-northwest of Crested Butte in west-central Colorado (fig. 1). Land-surface elevations in the watershed range from 9,600 to 12,200 feet (ft) (fig. 2 ). Vegetation is subalpine to alpine, consisting of dominantly mixed spruce and fir forest or tundra. The closest meteorological stations are in the town of Crested Butte at an elevation of 8,860 ft (http://www.wrcc.dri.edu), at Crested Butte Ski Area about $6 \mathrm{mi}$ to the northeast at an elevation of 10,160 ft, and at Schofield Pass about $10 \mathrm{mi}$ to the north at an elevation of 10,700 ft (http://www.wcc.nrcs.usda.gov/snotel). Data from these stations indicate that likely ranges (elevation-dependent) for mean annual air temperature, mean annual precipitation, and percentage of precipitation falling as snow for the Elk Creek watershed are $0^{\circ}$ to $2^{\circ} \mathrm{C}, 25$ to 50 inches (in), and 55 to 75 percent, respectively. Snow cover generally persists from November through May. Streamflow records for Elk Creek are available from 2008 onward (Jan Christner, URS Corporation, oral communication, February 2011), measured at the USEPA's ELK-00 site located at the mouth of Elk Creek just below sample site EC-CELK1 (fig. 2). Available data indicate baseflows on the order of 0.1 cubic feet per second (cfs), and spring high flows on the order of $10 \mathrm{cfs}$. The stream is perennial and snowmelt-dominated, with the majority of annual discharge occurring in April, May, and June.

The Standard Mine is an abandoned, underground, hardrock mine within the Ruby mining district that was mined intermittently from 1880 through the 1960s (Wood and Oerter, 2007). Metals mined at the deposit included silver, lead, zinc, and copper. The primary mineral deposit targeted was a polymetallic vein system associated with the Standard fault that contained sphalerite, pyrite, argentiferous galena, and chalcopyrite. Sharp (1978) concluded that the poly-metallic vein mineralization in the upper Elk Creek watershed (including the Standard fault vein) appear genetically and spatially related to an underlying Tertiary rhyolite porphyry stock, exposed to the northeast in Redwell basin. The mine consists of four adits and several stopes and shafts that generally follow the Standard fault vein (Colorado Division of Reclamation, Mining, and Safety, 2007). The adits are designated Levels 1, 2, 3, and 5, in sequence from lowermost to uppermost. The Level 1 and Level 5 portals are the only portals that consistently drain water. Level 1 discharges considerably more water than the other levels and thus is the largest potential source of metals in Elk Creek associated with the Standard Mine.

\section{Acknowledgments}

This work was done in cooperation with the USEPA. We greatly appreciate the efforts of Mackenzie Johnston, Jim Coogan, and Tom Sunderland for assisting in the sample collection. We thank Robert Runkel and Thomas Chapin of the USGS for reviewing this report and providing helpful comments.

\section{Methods}

\section{Sampling Sites}

Table 1 and Figure 2 provide sample site locations. One sample was collected from Level 1 portal discharge (ECMSTD1) and two samples were collected from Elk Creek (EC-CELK1 and EC-CELK2) at six different times during the Spring of 2010: March, $28^{\text {th }}$; April $22^{\text {nd }}$; May $6^{\text {th }}$ and $23^{\text {rd. }}$; and June $9^{\text {th }}$ and $21^{\text {st }}$. Sites EC-MSTD1 and EC-CELK1 were sampled previously by the USGS in 2006, 2007, and 2009 (Manning and others, 2008; Verplanck and others, 2010).

Table 1. Sample site information.

[ft, feet; m, meter; coordinates are Universal Transverse Mercator (UTM) coordinate system, North American Datum of 1983, Zone 13]

\begin{tabular}{lcclc}
\hline Site Name & $\begin{array}{c}\text { Easting } \\
(\mathbf{m})\end{array}$ & $\begin{array}{c}\text { Northing } \\
(\mathbf{m})\end{array}$ & \multicolumn{1}{c}{ Description } & $\begin{array}{c}\text { Elevation } \\
(\mathbf{f t})\end{array}$ \\
\hline EC-CELK1 & 321270 & 4302915 & Elk Creek near confluence with Coal Creek & 9,579 \\
EC-CELK2 & 319815 & 4304521 & Elk Creek near USEPA site ELK-08 & 10,558 \\
EC-MSTD1 & 320124 & 4305517 & Standard Mine, Level 1 Portal & 11,008 \\
\hline
\end{tabular}




\section{Water-Chemistry Sampling}

Measurements of $\mathrm{pH}$, specific conductance (SC), and temperature were taken in the field and again in the laboratory within five days of sample collection. Samples for major-ion and trace-element analyses were filtered onsite through a 0.45 -micrometer $(\mu \mathrm{m})$ capsule filter. Four of the six samples collected from EC-CELK1 (those collected May $6^{\text {th }}$ through June $21^{\text {st }}$ ) were also filtered through a $0.1-\mu \mathrm{m}$ syringe filter. Several sample aliquots were collected, including: an unfiltered, nitric acid acidified aliquot (raw acidified, or RA) for total-recoverable major cation and trace-element determinations; a 0.45- $\mu \mathrm{m}$ filtered, nitric acid acidified aliquot (filtered acidified, or FA) for dissolved major cation and trace-element determinations; a $0.45-\mu \mathrm{m}$ filtered, unacidified aliquot (filtered unacidified, or FU) for anion and alkalinity determinations; and a $0.45-\mu \mathrm{m}$ filtered, hydrochloric acid acidified aliquot (also FA) for iron redox species determinations. Additionally, a $0.1-\mu \mathrm{m}$ filtered, nitric acid acidified aliquot (FA 0.1) for dissolved major cation and trace-element determinations was collected for four of the samples from EC-CELK1. Bottles for FA, FA 0.1, and RA aliquots were presoaked in nitric acid, rinsed in distilled water, and prerinsed with sample water. Bottles for FU aliquots were presoaked in distilled water and prerinsed with sample water. Opaque bottles for iron redox aliquots were presoaked in hydrochloric acid, rinsed in distilled water, and prerinsed with sample water. Appropriate aliquots were acidified with ultrapure acid and then stored on ice until refrigerated. Samples for analysis of oxygen and hydrogen isotopic compositions $\left(\delta^{18} \mathrm{O}, \delta^{2} \mathrm{H}\right)$ of water were collected in borosilicate glass bottles (unfiltered, unpreserved).

\section{Laboratory Methods}

All reagents were of a purity at least equal to the reagentgrade standards of the American Chemical Society. Doubledistilled deionized water, and redistilled acids using a subboiling purification technique (Kuehner and others, 1972), were used in all preparations. The analytical method and detection limit for each analyte are listed in table 2. USGS standard reference water samples and blanks were included with each sample suite for inductively coupled plasma atomic-emission spectroscopy (ICP-AES) and inductively coupled plasma-mass spectrometry (ICP-MS). Major cations (calcium, magnesium, potassium, and sodium) and silica and selected trace elements (aluminum, boron, barium, cadmium, copper, iron, manganese, lead, strontium, and zinc) for total-recoverable and dissolved samples were determined using a Leeman Labs DRE-D ${ }^{\text {TM }}$ ICP-AES. Trace elements for total-recoverable and dissolved samples were analyzed with the Elan DCRe ICP-MS using a method developed by the U.S. Geological Survey (Meier and others, 1994; Lamothe and others, 2002). This method is used to directly determine the elements in the water samples without need for any preconcentration or dilution. Elemental detection limits are in the subparts per billion range (table 2), and the working linear range is six or more orders of magnitude.
Concentrations of major anions $\left(\mathrm{Cl}^{-}, \mathrm{F}^{-}, \mathrm{NO}_{3}^{-}\right.$and $\left.\mathrm{SO}_{4}^{-}\right)$ were determined by ion chromatography (Brinton and others, 1995) using a Dionex $600^{\mathrm{TM}}$ ion chromatograph with a 25-microliter injection loop. USGS standard-reference-water samples were used as independent quality-control standards. Alkalinity (as $\mathrm{HCO}_{3}^{-}$) was determined using an Orion $960^{\mathrm{TM}}$ autotitrator and standardized $\mathrm{H}_{2} \mathrm{SO}_{4}$ (Barringer and Johnsson, 1989). Samples were diluted as necessary to bring the analyte concentration within the optimal range of the method. Iron (II) and total iron were determined using a modification of the FerroZine ${ }^{\mathrm{TM}}$ colorimetric method (Stookey, 1970; To and others, 1999) with a Hewlett Packard $8453^{\text {TM }}$ diode array ultraviolet/ visible (UV/VIS) spectrophotometer.

Samples for analysis of oxygen $\left(\delta^{18} \mathrm{O}\right)$ and hydrogen $\left(\delta^{2} \mathrm{H}\right)$ isotopic compositions of water were analyzed by the U.S. Geological Survey Stable Isotope Laboratory in Denver, Colorado. Oxygen isotopic compositions were determined using a Micromass Optima with an automated $\mathrm{CO}_{2}$ equilibration technique adapted from Epstein and Mayeda (1953). Water samples were prepared for hydrogen-isotopic analyses using the zinc-reduction technique (Kendall and Coplen, 1985). The hydrogen analyses were performed on a Finnigan MAT 252 mass spectrometer. Values of $\delta^{18} \mathrm{O}$ and $\delta^{2} \mathrm{H}$ were relative to Vienna Standard Mean Ocean Water (VSMOW), and they have reproducibility of approximately 0.2 and 1.0 permil, respectively.

\section{Data Quality}

Field and laboratory measurements of SC were in close agreement (generally within 5\%). Field and laboratory measurements of $\mathrm{pH}$ showed similar temporal variations, but often differed somewhat; field $\mathrm{pH}$ was commonly 10 to 20 percent lower than lab $\mathrm{pH}$. Testing of the two different meters used to measure field and laboratory $\mathrm{pH}$ immediately after the sampling period revealed that, although the field $\mathrm{pH}$ meter performed well in calibration standards, it equilibrated slowly and read as much as $0.2 \mathrm{pH}$ units low in acidic natural waters and $1.0 \mathrm{pH}$ unit low in circum-neutral natural waters compared to other $\mathrm{pH}$ probes tested in the laboratory. The laboratory $\mathrm{pH}$ measurements may have differed slightly from the $\mathrm{pH}$ of sampled water in the field given that it was measured days after sample collection. It is thus difficult to determine whether field or laboratory $\mathrm{pH}$ is more reliable. Both measurements are provided in this report (table 3 ). However, all figures and discussion involving $\mathrm{pH}$ henceforth refer to field $\mathrm{pH}$ measurements because only the field $\mathrm{pH}$ data are available for all six sampling events.

Quality control included replicate samples, field-equipment blanks, analyses by alternative methods, analysis of standard reference water samples, and calculation of charge imbalance. Replicate samples are two field-collected samples that are considered to be essentially identical in composition and are used to estimate variability in environmental data. Replicate samples were collected immediately following the environmental sample. Each replicate sample was processed 
Table 2. Methods of analysis and detection limits.

$[\mathrm{mg} / \mathrm{L}$, milligram per liter; $\mu \mathrm{g} / \mathrm{L}$, microgram per liter; IC, ion chromatography; ICP-MS, inductively coupled plasma-mass spectrometry; ICP-AES, inductively coupled plasma-atomic emission spectroscopy]

\begin{tabular}{|c|c|c|c|c|c|}
\hline Element & Detection limit & Method & Element & Detection limit & Method \\
\hline $\mathrm{Ag}$ & $1 \mu \mathrm{g} / \mathrm{L}$ & ICP-MS & $\mathrm{Mn}$ & $1 \mu \mathrm{g} / \mathrm{L}$ & ICP-AES \\
\hline $\mathrm{Al}$ & $80 \mu \mathrm{g} / \mathrm{L}$ & ICP-AES & $\mathrm{Mn}$ & $0.2 \mu \mathrm{g} / \mathrm{L}$ & ICP-MS \\
\hline $\mathrm{Al}$ & $2 \mu \mathrm{g} / \mathrm{L}$ & ICP-MS & Mo & $2 \mu \mathrm{g} / \mathrm{L}$ & ICP-MS \\
\hline As & $1 \mu \mathrm{g} / \mathrm{L}$ & ICP-MS & $\mathrm{Na}$ & $1 \mathrm{mg} / \mathrm{L}$ & ICP-AES \\
\hline B & $10 \mu \mathrm{g} / \mathrm{L}$ & ICP-AES & $\mathrm{Nb}$ & $0.2 \mu \mathrm{g} / \mathrm{L}$ & ICP-MS \\
\hline $\mathrm{Ba}$ & $0.8 \mu \mathrm{g} / \mathrm{L}$ & ICP-AES & $\mathrm{Nd}$ & $0.01 \mu \mathrm{g} / \mathrm{L}$ & ICP-MS \\
\hline $\mathrm{Ba}$ & $0.2 \mu \mathrm{g} / \mathrm{L}$ & ICP-MS & $\mathrm{Ni}$ & $0.4 \mu \mathrm{g} / \mathrm{L}$ & ICP-MS \\
\hline $\mathrm{Be}$ & $0.05 \mu \mathrm{g} / \mathrm{L}$ & ICP-MS & $\mathrm{NO}_{3}^{-}$ & $0.05 \mathrm{mg} / \mathrm{L}$ & IC \\
\hline $\mathrm{Bi}$ & $0.2 \mu \mathrm{g} / \mathrm{L}$ & ICP-MS & $\mathrm{P}$ & $10 \mu \mathrm{g} / \mathrm{L}$ & ICP-MS \\
\hline $\mathrm{Ca}$ & $0.02 \mathrm{mg} / \mathrm{L}$ & ICP-AES & $\mathrm{Pb}$ & $7 \mu \mathrm{g} / \mathrm{L}$ & ICP-AES \\
\hline $\mathrm{Cd}$ & $1 \mu \mathrm{g} / \mathrm{L}$ & ICP-AES & $\mathrm{Pb}$ & $0.05 \mu \mathrm{g} / \mathrm{L}$ & ICP-MS \\
\hline $\mathrm{Cd}$ & $0.02 \mu \mathrm{g} / \mathrm{L}$ & ICP-MS & $\operatorname{Pr}$ & $0.01 \mu \mathrm{g} / \mathrm{L}$ & ICP-MS \\
\hline $\mathrm{Ce}$ & $0.01 \mu \mathrm{g} / \mathrm{L}$ & ICP-MS & $\mathrm{Rb}$ & $0.01 \mu \mathrm{g} / \mathrm{L}$ & ICP-MS \\
\hline $\mathrm{Cl}^{-}$ & $0.1 \mathrm{mg} / 1$ & $\mathrm{IC}$ & $\mathrm{Sb}$ & $0.3 \mu \mathrm{g} / \mathrm{L}$ & ICP-MS \\
\hline Co & $0.02 \mu \mathrm{g} / \mathrm{L}$ & ICP-MS & $\mathrm{Sc}$ & $0.6 \mu \mathrm{g} / \mathrm{L}$ & ICP-MS \\
\hline $\mathrm{Cr}$ & $1 \mu \mathrm{g} / \mathrm{L}$ & ICP-MS & $\mathrm{Se}$ & $1 \mu \mathrm{g} / \mathrm{L}$ & ICP-MS \\
\hline Cs & $0.02 \mu \mathrm{g} / \mathrm{L}$ & ICP-MS & $\mathrm{SiO}_{2}$ & $0.06 \mathrm{mg} / \mathrm{L}$ & ICP-AES \\
\hline $\mathrm{Cu}$ & $3 \mu \mathrm{g} / \mathrm{L}$ & ICP-AES & $\mathrm{SO}_{4}^{-}$ & $0.1 \mathrm{mg} / \mathrm{L}$ & IC \\
\hline $\mathrm{Cu}$ & $0.5 \mu \mathrm{g} / \mathrm{L}$ & ICP-MS & $\mathrm{Sm}$ & $0.01 \mu \mathrm{g} / \mathrm{L}$ & ICP-MS \\
\hline Dy & $0.005 \mu \mathrm{g} / \mathrm{L}$ & ICP-MS & $\mathrm{Sr}$ & $0.7 \mu \mathrm{g} / \mathrm{L}$ & ICP-AES \\
\hline $\mathrm{Er}$ & $0.005 \mu \mathrm{g} / \mathrm{L}$ & ICP-MS & $\mathrm{Sr}$ & $0.5 \mu \mathrm{g} / \mathrm{L}$ & ICP-MS \\
\hline $\mathrm{Eu}$ & $0.005 \mu \mathrm{g} / \mathrm{L}$ & ICP-MS & $\mathrm{Ta}$ & $0.02 \mu \mathrm{g} / \mathrm{L}$ & ICP-MS \\
\hline $\mathrm{F}^{-}$ & $0.05 \mathrm{mg} / 1$ & IC & $\mathrm{Tb}$ & $0.005 \mu \mathrm{g} / \mathrm{L}$ & ICP-MS \\
\hline $\mathrm{Fe}$ & $3 \mu \mathrm{g} / \mathrm{L}$ & ICP-AES & Th & $0.2 \mu \mathrm{g} / \mathrm{L}$ & ICP-MS \\
\hline $\mathrm{Fe}$ & $2 \mu \mathrm{g} / \mathrm{L}$ & FerroZine & $\mathrm{Ti}$ & $0.5 \mu \mathrm{g} / \mathrm{L}$ & ICP-MS \\
\hline $\mathrm{Fe}(\mathrm{II})$ & $2 \mu \mathrm{g} / \mathrm{L}$ & FerroZine & $\mathrm{Tl}$ & $0.1 \mu \mathrm{g} / \mathrm{L}$ & ICP-MS \\
\hline $\mathrm{Ga}$ & $0.05 \mu \mathrm{g} / \mathrm{L}$ & ICP-MS & $\mathrm{Tm}$ & $0.005 \mu \mathrm{g} / \mathrm{L}$ & ICP-MS \\
\hline Gd & $0.005 \mu \mathrm{g} / \mathrm{L}$ & ICP-MS & $\mathrm{U}$ & $0.1 \mu \mathrm{g} / \mathrm{L}$ & ICP-MS \\
\hline Но & $0.005 \mu \mathrm{g} / \mathrm{L}$ & ICP-MS & $\mathrm{V}$ & $0.5 \mu \mathrm{g} / \mathrm{L}$ & ICP-MS \\
\hline K & $0.03 \mathrm{mg} / \mathrm{L}$ & ICP-AES & $\mathrm{W}$ & $0.5 \mu \mathrm{g} / \mathrm{L}$ & ICP-MS \\
\hline $\mathrm{K}$ & $0.03 \mu \mathrm{g} / \mathrm{L}$ & ICP-MS & $\mathrm{Y}$ & $0.01 \mu \mathrm{g} / \mathrm{L}$ & ICP-MS \\
\hline $\mathrm{La}$ & $0.01 \mu \mathrm{g} / \mathrm{L}$ & ICP-MS & $\mathrm{Yb}$ & $0.01 \mu \mathrm{g} / \mathrm{L}$ & ICP-MS \\
\hline $\mathrm{Li}$ & $0.1 \mu \mathrm{g} / \mathrm{L}$ & ICP-MS & $\mathrm{Zn}$ & $2 \mu \mathrm{g} / \mathrm{L}$ & ICP-AES \\
\hline $\mathrm{Mg}$ & $0.002 \mathrm{mg} / \mathrm{L}$ & ICP-AES & $\mathrm{Zn}$ & $3 \mu \mathrm{g} / \mathrm{L}$ & ICP-MS \\
\hline
\end{tabular}


through all the steps of the environmental sample using a new filter and clean equipment. Replicate samples were analyzed at the same time using the same instruments as the other samples collected during the same sampling trip. Analytical results of replicate samples are included in tables 3 and 4, and follow the associated environmental sample (sample name ending with $\mathrm{R})$. Most major, minor, and trace-element replicate concentrations are within \pm 10 percent of the corresponding environmental sample.

A field-equipment blank is a sample prepared using deionized water passed through all the sampling and processing equipment. This type of sample is used to check for the potential contamination of the water-chemistry samples during collection, processing, handling, and analysis. Analytical results are included in tables 3 and 4, designated EB-08 and EB-09 (equipment blank). All analytes were below analytical detection limits except for bicarbonate alkalinity, which was consistently measured at $2 \mathrm{mg} / \mathrm{L}$, just above the reporting limit.

Concentrations of cations were determined by ICP-AES and ICP-MS. Good agreement between ICP-AES and ICP-MS results was observed for constituents with concentrations at least three times the detection limit (fig. 3). Barium, calcium, manganese, strontium, and zinc were chosen for comparison in Figure 3 because the range in concentrations of these elements was within the working range of both analytical techniques.

Data for all samples with complete analyses were checked using the computer program WATEQ4F (Ball and Nordstrom, 1991) for charge imbalance (C.I.), using the following calculation:

$$
\text { C.I. }(\text { percent })=\frac{100 *(\text { sum cations }- \text { sum anions })}{(\text { sum cations }+ \text { sum anions }) / 2}
$$

where sum cations is the sum of the cations in milliequivalents per liter, and sum anions is the sum of the anions in milliequivalents per liter. The percent-charge imbalance reflects how well the major anions and cations balance and usually is an independent measure of the accuracy of the analytical techniques. The percent-charge imbalance was low (less than 10 percent) for all samples (table 3 ) except four of the most dilute samples for which the imbalance was approximately 15 percent. This is not uncommon for dilute samples because analytical uncertainty increases at concentrations approaching instrument detection limits, and unmeasured organic anions can be important in dilute samples.

\section{Results}

\section{Snowmelt Runoff Hydrology}

Snowpack measurements are not available for the Elk Creek watershed. However, two snowpack telemetry (SNOTEL) sites are relatively close: Butte is located about $6 \mathrm{mi}$ to the northeast, and Schofield Pass is about $10 \mathrm{mi}$ to the north (http://www.wcc.nrcs.usda.gov/snotel). Schofield Pass was chosen as the most representative site because its elevation of $10,700 \mathrm{ft}$ is closer to the mean elevation of the Elk Creek watershed (about 10,900 ft). Figure 4A shows snow water equivalent (SWE) data for Schofield Pass for the period of March $1^{\text {st }}$ to July $1^{\text {st }}$ for the years 2010 and 2007. Mean SWE for years 1986 to 2010 is also shown for reference. The year 2007 is shown in addition to 2010 because water-chemistry data for these two years are discussed and compared below. 2010 maximum SWE at Schofield Pass was near average, and 2007 maximum SWE was 20 percent below average.

Elk Creek streamflows have been measured since 2008, but this is too short a period to provide meaningful average flows against which 2010 and 2007 flows can be compared. The nearest available stream gage with a long-term record is a USGS station on the East River located about $12 \mathrm{mi}$ to the southeast just downstream from the confluence with Cement Creek (http://waterdata.usgs.gov/co/nwis/rt). Figure 4B shows East River streamflow data for the period of March $1^{\text {st }}$ to July $1^{\text {st }}$ for the years 2010 and 2007. Mean, $25^{\text {th }}$ percentile, and $75^{\text {th }}$ percentile flows for years 1964 to 2010 also are shown for reference. Discharge during spring runoff in 2010 was generally average to above average. 2007 flows are near average early in the runoff period, but during late May and early June (when annual maximum flows typically occur) flows are generally less than the $25^{\text {th }}$ percentile, indicating below-average total spring runoff.

The SWE data from Schofield Pass suggest that the amount of water stored in the snowpack in the Elk Creek watershed was near average prior to snowmelt in 2010, and below average in 2007. Similarly, streamflow data from the East River suggest that spring runoff flows in Elk Creek were near average in 2010 and below average in 2007. In short, available meteorological and hydrologic information suggest that the water-quality data collected in spring 2010 are representative of an average water year, and those collected in spring 2007 are representative of a low-water year.

Figure 5 shows 2010 streamflow data for the ELK-00 gage on Elk Creek, located immediately downstream of sampling site EC-CELK1 (fig. 2), and the gage at the Level 1 portal, co-located with sampling site EC-MSTD1. 2010 flows for the East River and 2010 SWE for Schofield Pass are also shown. Photographs in Figures 6 and 7 display changes in snowpack at the Level 1 portal and changes in flow in Elk Creek through the spring of 2010. Flow at all three stream gage sites followed a similar pattern during the 2010 snowmelt runoff period. Peak flows occurred within the period of June $7^{\text {th }}$ to $9^{\text {th }}$, with flows at the Level 1 portal, ELK-00, and East River reaching $0.30,24$, and 2,700 cfs, respectively. These peak flows were 1.5 to 2 orders of magnitude greater than baseflows in early March. Flows are closely correlated with Schofield Pass SWE; constant or decreasing flows correspond to periods of constant or increasing SWE, and increasing flows correspond to periods of decreasing SWE (snowmelt). A unique feature of the flow record at all three sites is a drop in late April that leads to a double peak. This drop is synchronous 
A

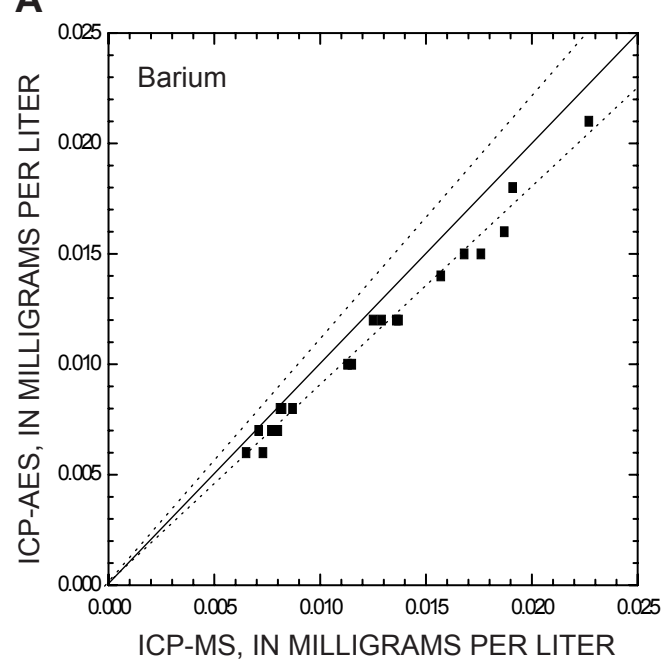

C

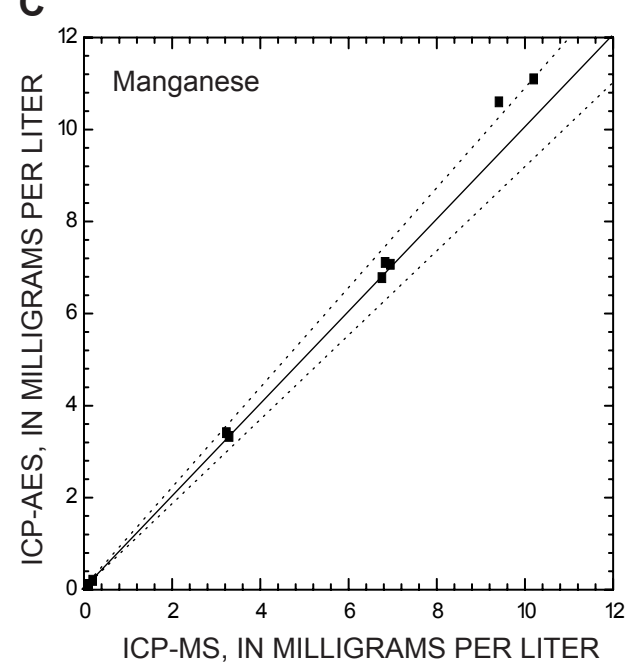

B

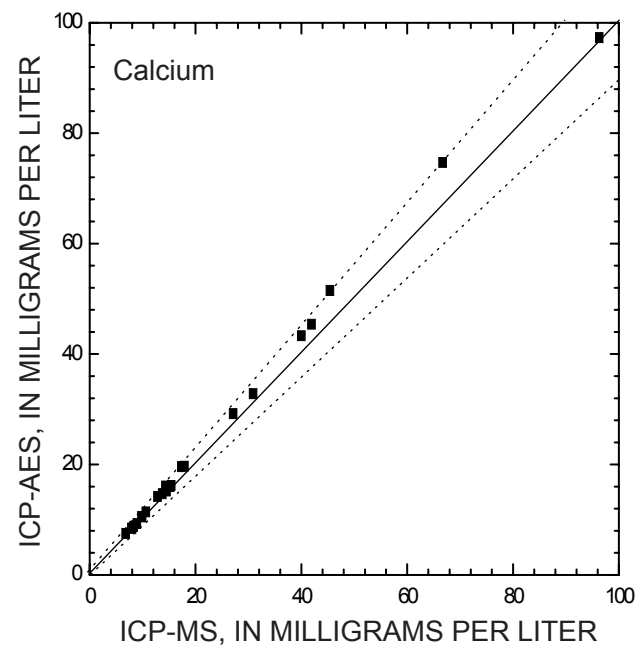

D

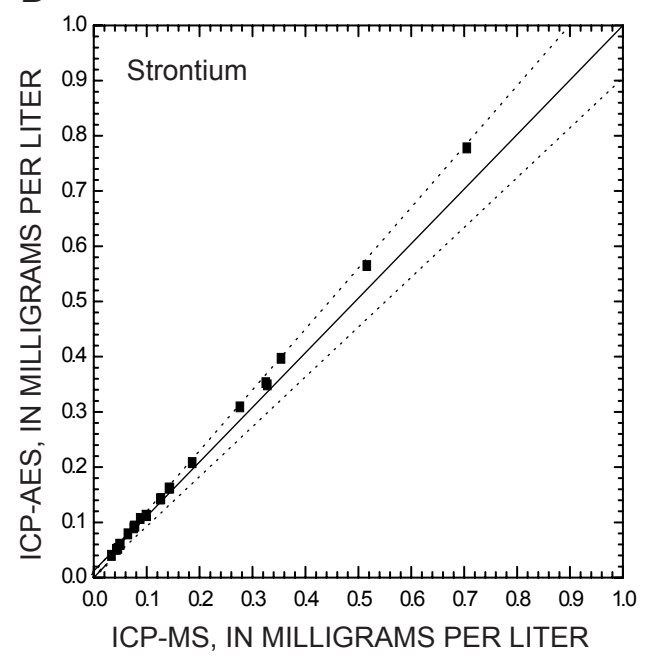

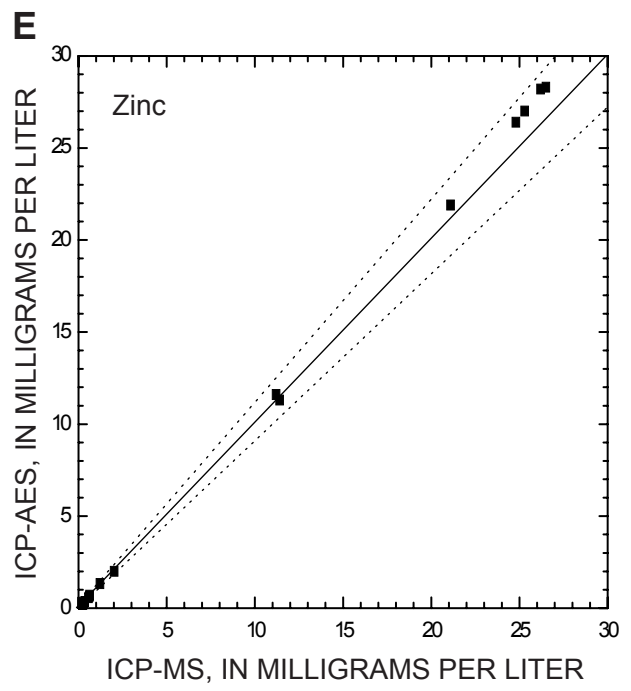

Figure 3. Comparison of analytical results by using ICP-MS (inductively coupled plasma-mass spectrometry) and ICP-AES (inductively coupled plasma-atomic emission spectroscopy). Barium (A), calcium (B), manganese (C), strontium (D), and zinc (E) concentration. Solid diagonal line, 1:1 correspondence; dashed line, 10 percent variation. 
A

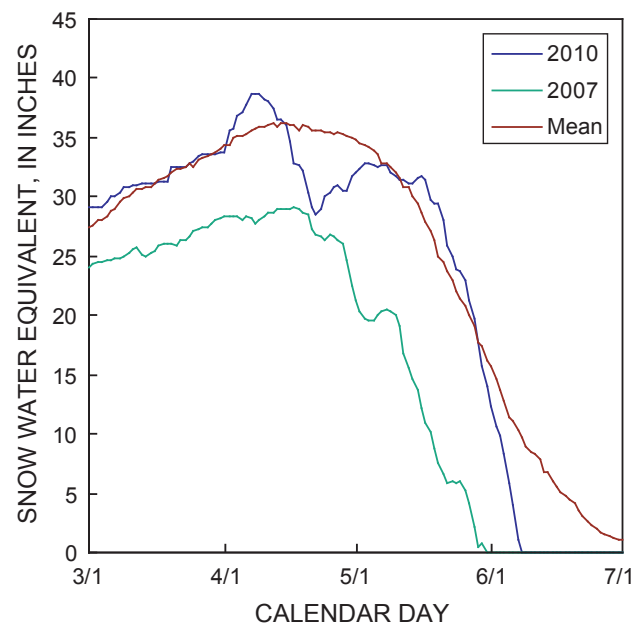

B

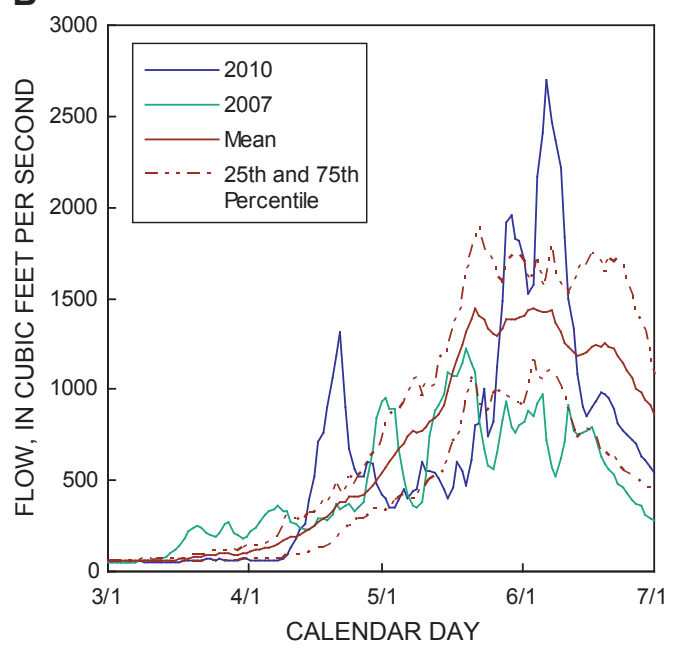

Figure 4. Snow water equivalent data from Schofield Pass snow telemetry site (A) and streamflow data from the East River near the town of Crested Butte (B) for the years 2007 and 2010 compared to mean values. Mean snow water equivalent is for years 1986 to 2010 . Mean, $25^{\text {th }}$ percentile, and $75^{\text {th }}$ percentile streamflow values are for years 1964 to 2010.

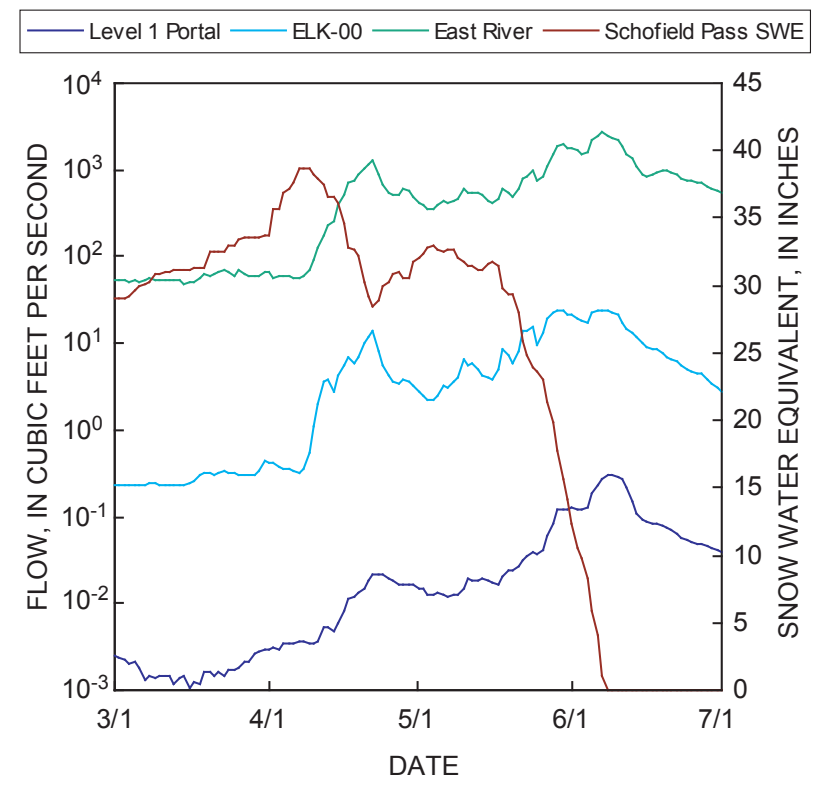

Figure 5. Streamflow records for the Level 1 portal, ELK-00 gage, and the USGS East River gage for the spring of 2010. Snow water equivalent (SWE) measured at the Schofield Pass snow telemetry site is also shown. 


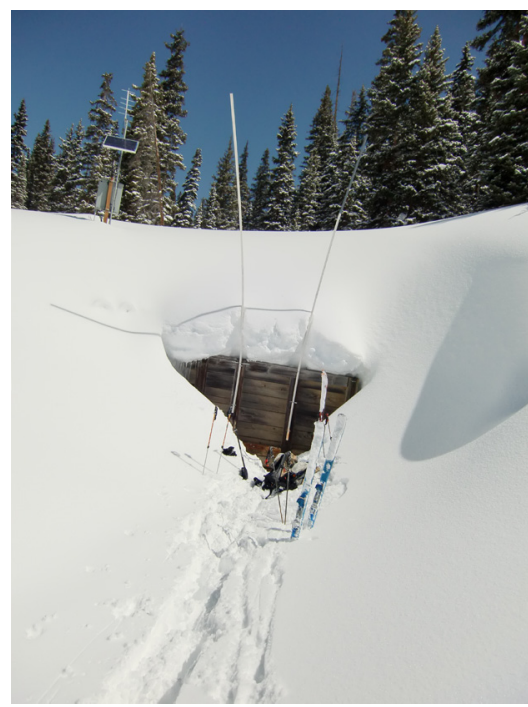

(A) March 28, Schofield Pass SWE 33.6 inches.

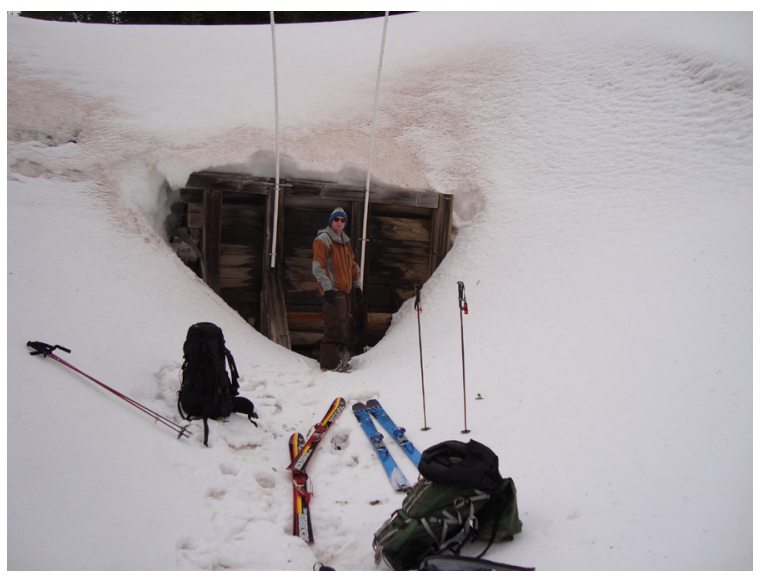

(C) May 6, Schofield Pass SWE 32.5 inches.

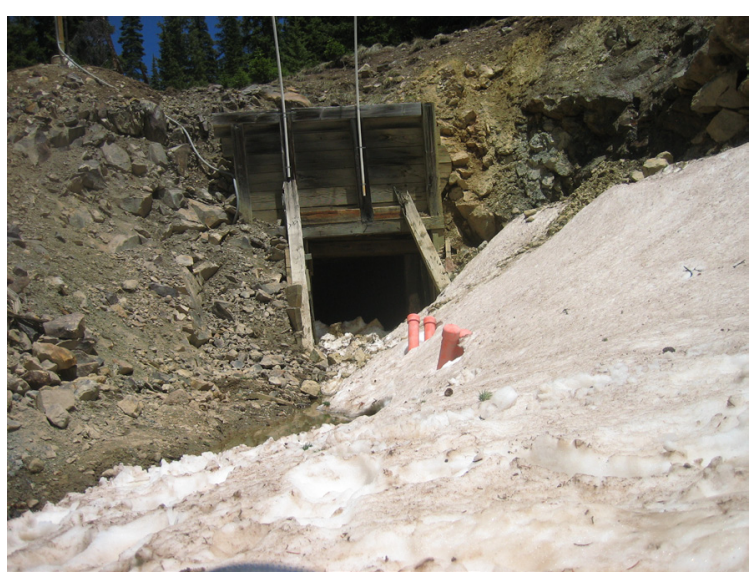

(E) June 9, Schofield Pass SWE 0.0 inches.

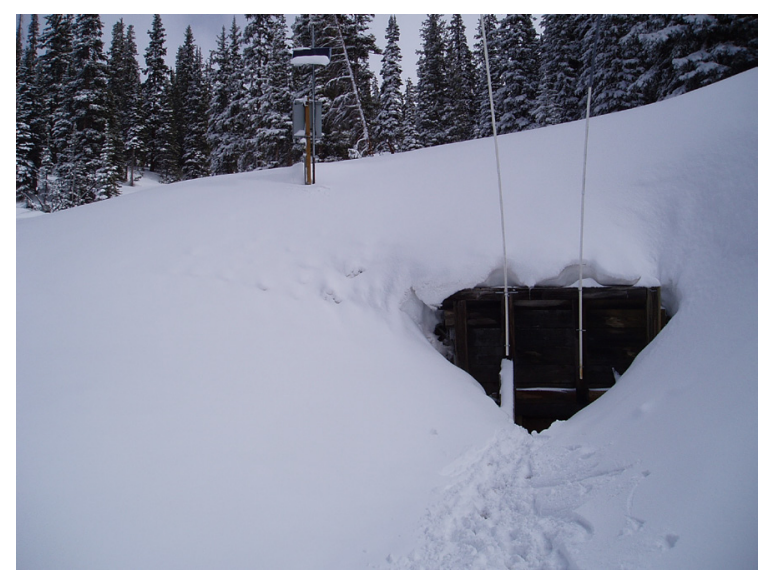

(B) April 22, Schofield Pass SWE 28.5 inches.

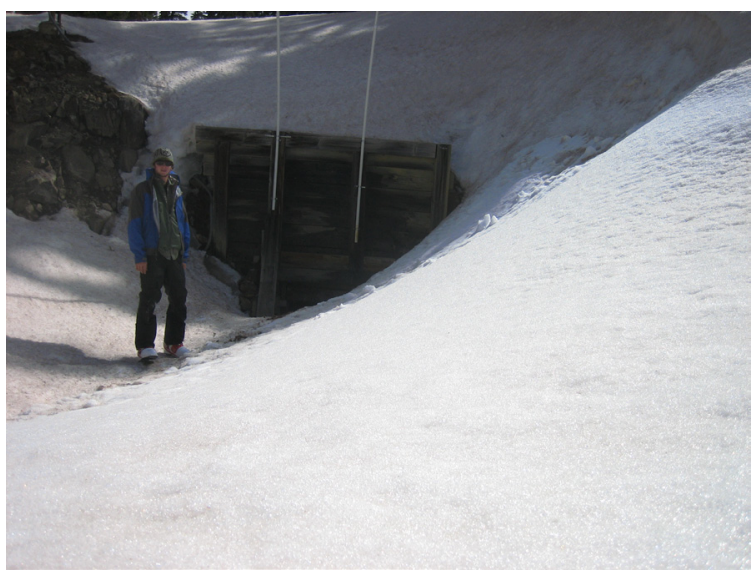

(D) May 23, Schofield Pass SWE 24.9 inches.

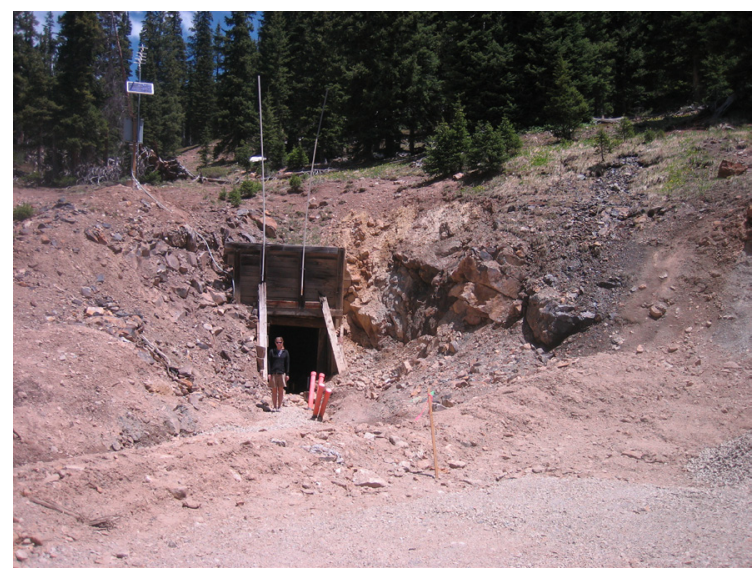

(F) June 21, Schofield Pass SWE 0.0 inches.

Figure 6. Photographs showing snowpack at the Level 1 portal on the six sampling days (A through F) during the spring of 2010. Snow water equivalent (SWE) values are from the Schofield Pass snow telemetry site. 


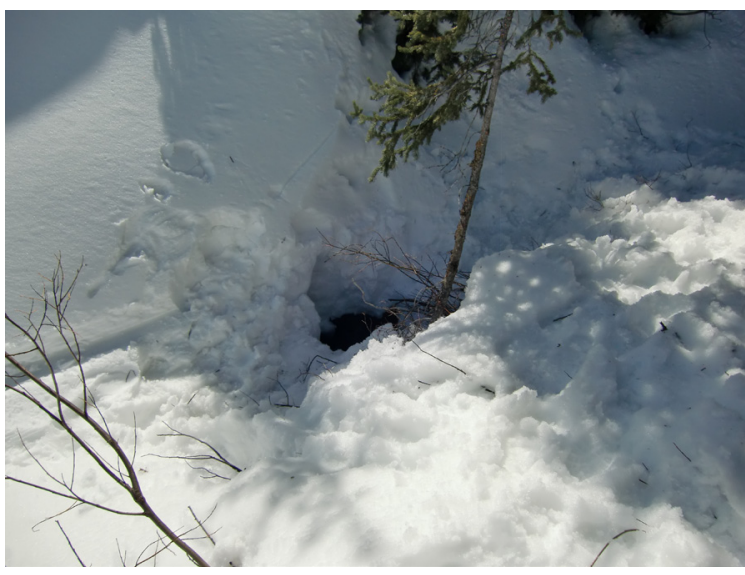

(A) March 28, ELK-00 flow 0.30 cfs.

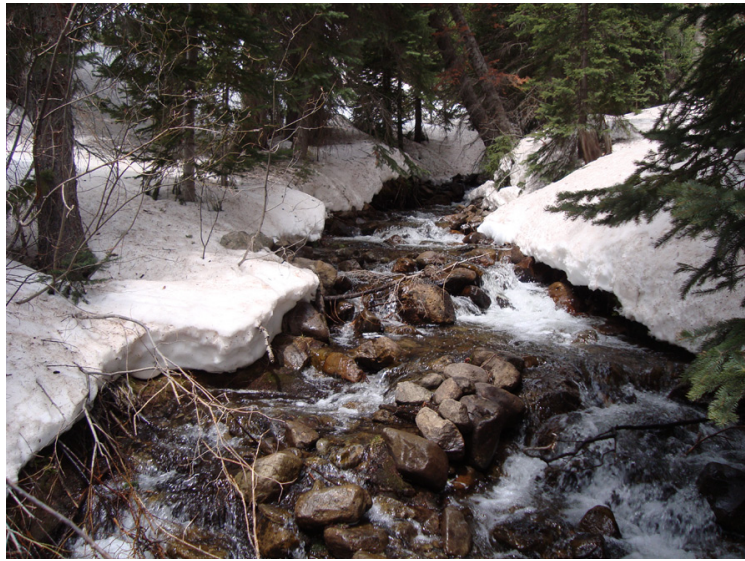

(C) May 6, ELK-00 flow 3.3 cfs.

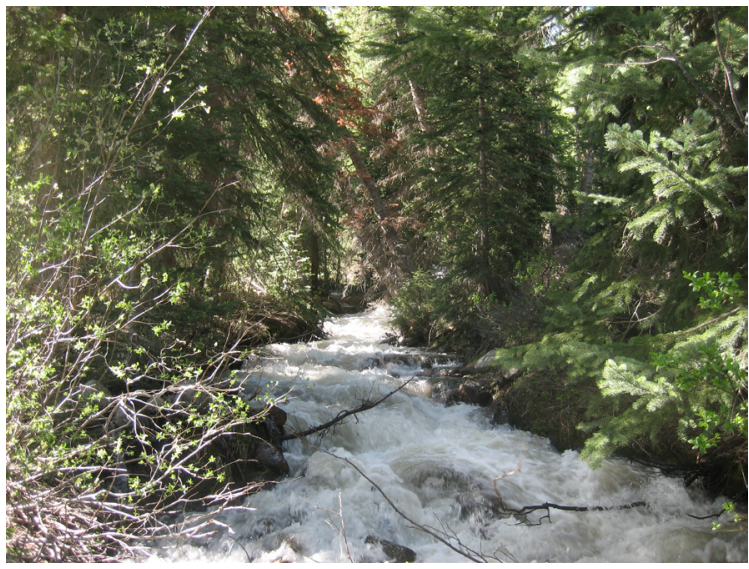

(E) June 9, ELK-00 flow 23 cfs.

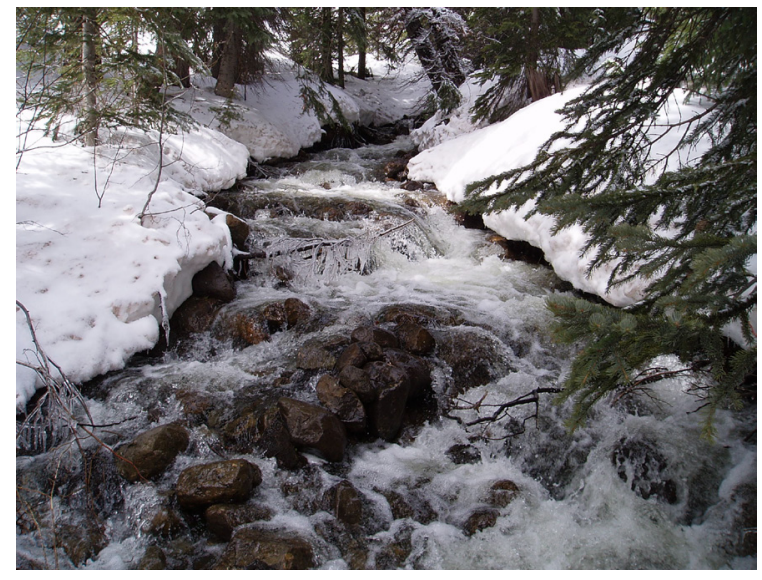

(B) April 22, ELK-00 flow 14 cfs.

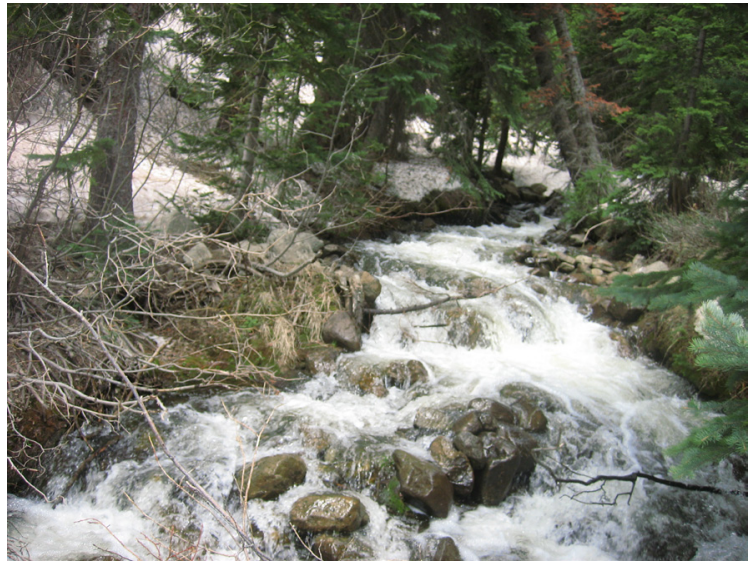

(D) May 23, ELK-00 flow 14 cfs.

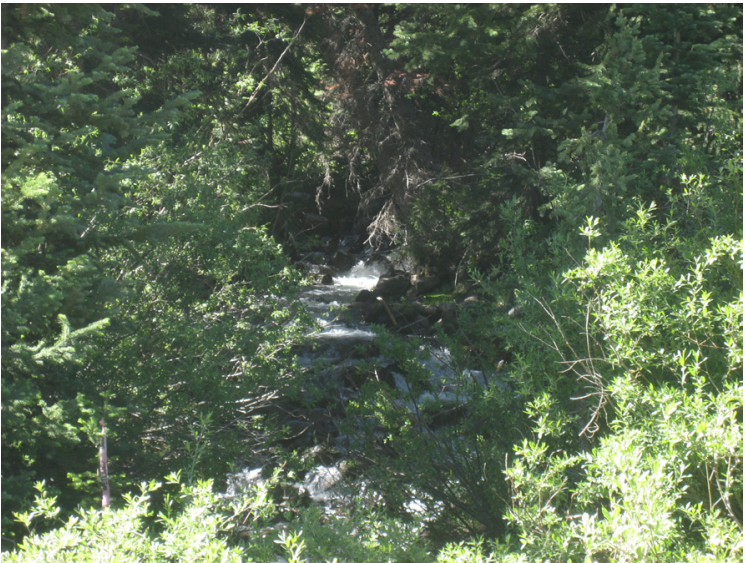

(F) June 21, ELK-00 flow 6.4 cfs.

Figure 7. Photographs showing flow in Elk Creek on the six sampling days (A through F) during the spring of 2010. Flow values (in cubic feet per second, or cfs) are from the ELK-00 gage located immediately downstream from sampling site EC-CELK1 where all photos were taken. All views are looking upstream from the sampling site, except photo $\mathrm{A}$ (March $28^{\text {th }}$ ) which shows the sampling hole dug through snow that completely covered the stream. 
with a distinct rebound in SWE that causes a similar double peak in the SWE curve. A close correlation between SWE and flow is expected for the two surface water sites, but is less intuitive for the Level 1 portal given that snowmelt water must flow as groundwater through a substantial mass of rock (tunnel overburden thickness of up to $1000 \mathrm{ft}$ ) prior to reaching Level 1. The rapid response of Level 1 portal flow to the onset of snowmelt ( $<3$ days) is consistent with geochemical and environmental tracer data collected previously from the Level 1 portal (Manning and others, 2008) which indicate short residence times $(<1$ year) for groundwater discharging from the Standard Mine.

\section{Water Chemistry}

\section{Major lons and Trace Elements}

The following discussion focuses on the field parameters $\mathrm{pH}$ and $\mathrm{SC}$; the major ions calcium $(\mathrm{Ca})$ and sulfate $\left(\mathrm{SO}_{4}\right)$; and the metals zinc $(\mathrm{Zn})$, cadmium $(\mathrm{Cd})$, manganese $(\mathrm{Mn})$, lead $(\mathrm{Pb})$, and copper $(\mathrm{Cu})$ to remain consistent with previous reports (Manning and others, 2008; Verplanck and others, 2010). All concentrations discussed are dissolved concentrations unless otherwise noted. Field parameter values, major-ion concentrations, and metal concentrations measured in 2007 (Manning and others, 2008) and in 2010 at sites ECMSTD1 and EC-CELK1 are compared on box-and-whisker plots in Figure 8. For EC-MSTD1, 2007 and 2010 values are similar, though the range of values measured in 2010 is larger than in 2007 for most constituents. The lower minimum concentrations in 2010 may be due to greater dilution resulting from higher flows at the Level 1 portal in 2010 (fig. 4). It is also possible that variations in the chemistry of Level 1 portal discharge in 2007 actually were as large as in 2010, but the full range simply was not captured by the samples collected. For EC-CELK1, 2007 and 2010 values are similar for the field parameters and major ions. As at EC-MSTD1, 2010 values cover a larger range than 2007 (pH excepted), and possible reasons for this are the same as explained above. However, metal concentrations are notably lower in 2010 than in 2007. Maximum concentrations of $\mathrm{Zn}, \mathrm{Cd}$, and $\mathrm{Mn}$ are 60 to 90 percent lower, and maximum concentrations of $\mathrm{Pb}$ and $\mathrm{Cu}$ are about 50 percent lower. The lower concentrations may be due to remedial efforts at the Standard Mine site implemented after 2007, including the installation of a bioreactor for treating Level 1 portal discharge (just downstream of ECMSTD1) and the relocation of waste rock and tailings (URS Operating Services, 2010). The lower values also may be due to greater dilution resulting from higher flows in Elk Creek in 2010 (fig. 4).

Figures 9, 10, and 11 show temporal trends in field $\mathrm{pH}$ and SC, major-ion concentrations, and selected metal concentrations at all three sample sites through the spring of 2010. Flow records for the Level 1 portal and ELK-00 also are shown for reference. Field $\mathrm{pH}$ and $\mathrm{SC}$ values display a first-order trend of decreasing during spring high flows, as observed in 2007 (fig. 9). At the Level 1 portal, the largest $\mathrm{pH}$ drop (from about 6 to about 3) occurs early in the spring runoff period, apparently due to the mobilization of a low-pH water source in the early stages of snowmelt. Specific conductance is apparently dilution-controlled, with lower values well correlated with higher flows and vice versa. Both of these patterns were observed in the 2007 data as well. Like SC, major-ion concentrations are in general inversely proportional to flow and appear to be dilution-controlled (fig. 10). The same was observed in 2007. A distinct late-April rebound in majorion concentrations, which otherwise decrease from March to early June, clearly corresponds to a late-April cold spell and associated decrease in streamflow evident in both flow records (though subtle at the Level 1 portal).

Metal concentrations follow two types of temporal patterns (fig. 11). Zinc and Cd follow an apparently dilutioncontrolled pattern similar to SC and the major ions. Lead and $\mathrm{Cu}$ follow an apparently $\mathrm{pH}$-controlled pattern, with concentrations inversely correlated with $\mathrm{pH}$. Lead and $\mathrm{Cu}$ thus rise rather than fall during spring high flows. Dissolved concentrations of $\mathrm{Pb}$ and $\mathrm{Cu}$ are known to be $\mathrm{pH}$-sensitive; when the $\mathrm{pH}$ drops below 4-5, these metals transition from a mainly sorbed state (onto suspended sediment particles) to a mainly dissolved state (Dzombak and Morel, 1990). The same temporal patterns for $\mathrm{Zn}, \mathrm{Cd}, \mathrm{Pb}$, and $\mathrm{Cu}$ were observed for in 2007. Manganese at the Level 1 portal is apparently dilution-controlled, as observed in 2007. However, Mn at site EC-CELK2 follows a pattern that is apparently both dilution-controlled and $\mathrm{pH}$-controlled, the former dominating late in the runoff cycle and the latter dominating early in the runoff cycle. Zinc and $\mathrm{Cd}$ concentrations increase slightly at the onset of snowmelt, as seen in 2007, suggesting that the low-pH water mobilized early in the snowmelt period is also elevated in $\mathrm{Zn}$ and $\mathrm{Cd}$. The source of this water is unknown (Manning and others, 2008), but it could be water within the mine workings that is relatively immobile during the rest of the year (and exposed to oxygen), such as water in muck/debris piles or in stagnant puddles on the tunnel floors.

Temporal patterns in $\mathrm{Zn}, \mathrm{Cd}$, and $\mathrm{Mn}$ concentrations in Elk Creek display notable differences in 2007 and 2010. In 2007, these metals spiked during spring runoff. In 2010, they decreased at EC-CELK2 and remained essentially constant at EC-CELK1. As with the lower overall concentrations of these metals in 2010 (fig. 8), the absence of the spike during high flow in 2010 could be the result of either remedial efforts at the Standard Mine site or dilution caused by higher flows in 2010 (fig. 4).

Manning and others (2008) hypothesized that Level 1 portal discharge was the primary source of metals in Elk Creek based on temporal patterns in metal concentrations and on metal load estimates made using flow measurements from September 2006. Metal concentration patterns for the 2010 samples (fig. 11) also are generally consistent with this hypothesis. Metal concentrations decrease with distance downstream from the Level 1 portal, and metals that decrease at the Level 1 portal during spring runoff also generally decrease in 
(A) Sample Site EC-MSTD1
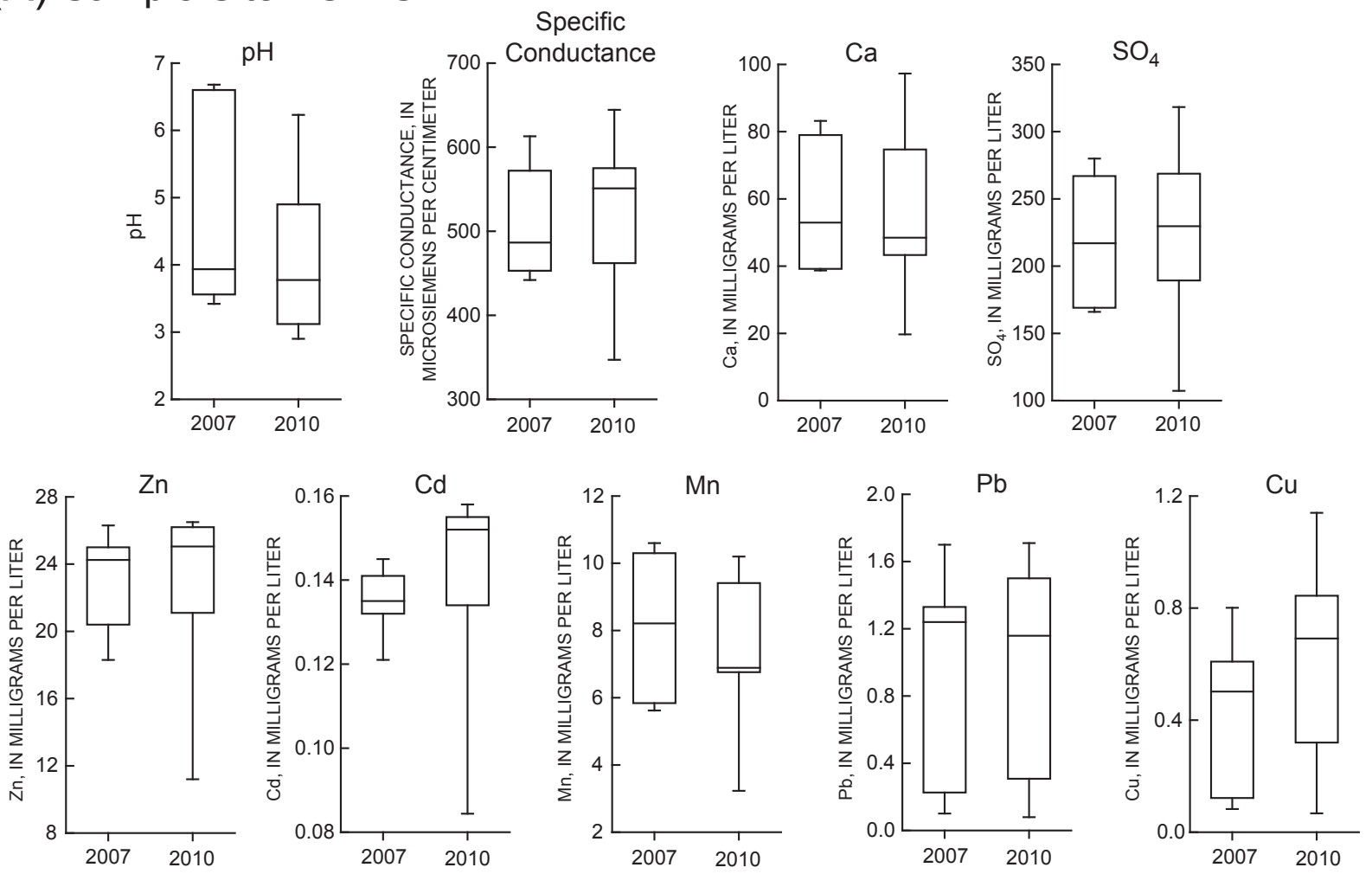

(B) Sample Site EC-CELK1
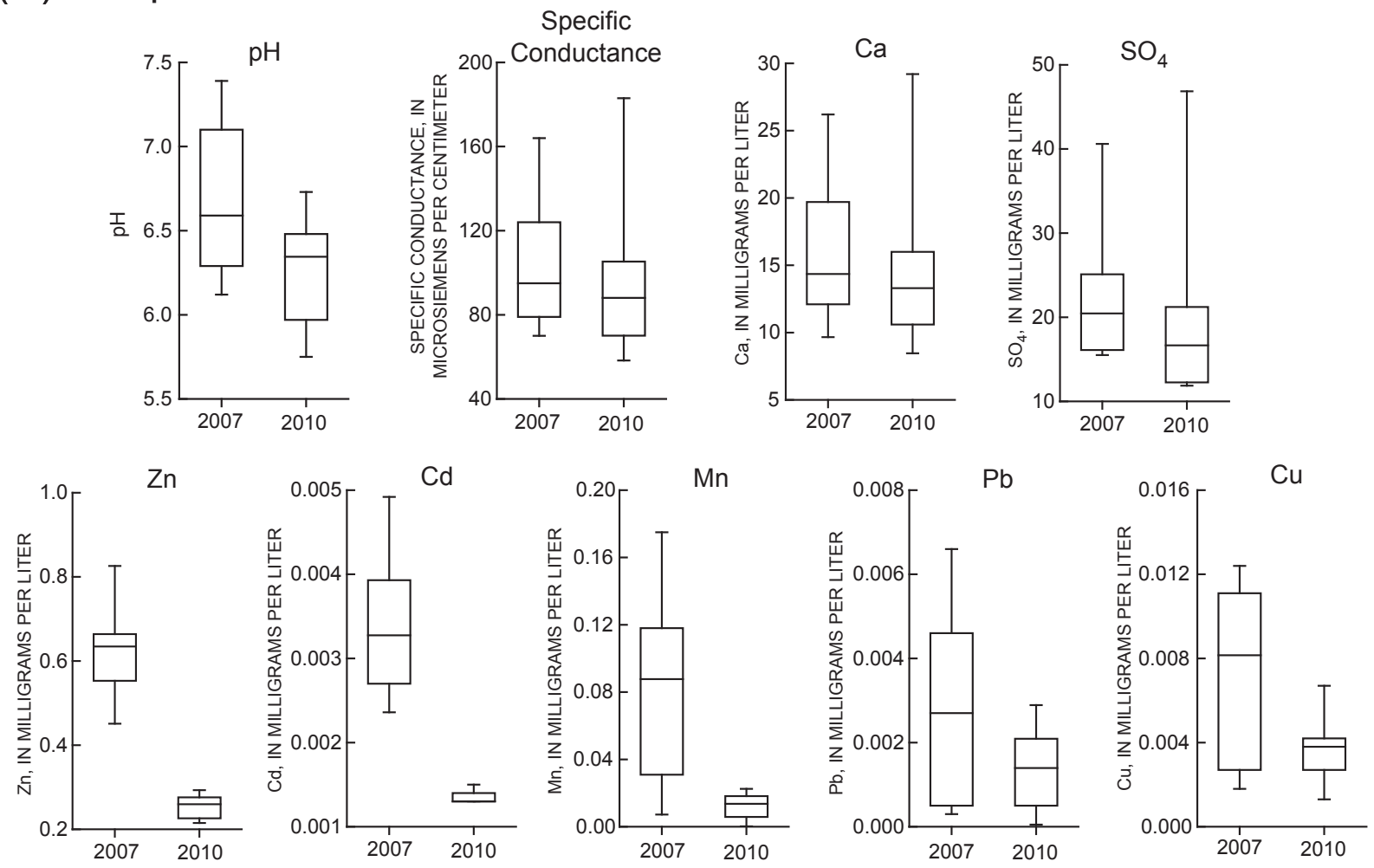

Figure 8. Box-and-whisker plots comparing 2007 and 2010 measurements at sample site EC-MSTD1 (A) and sample site EC-CELK1 (B). Each year includes six samples. 

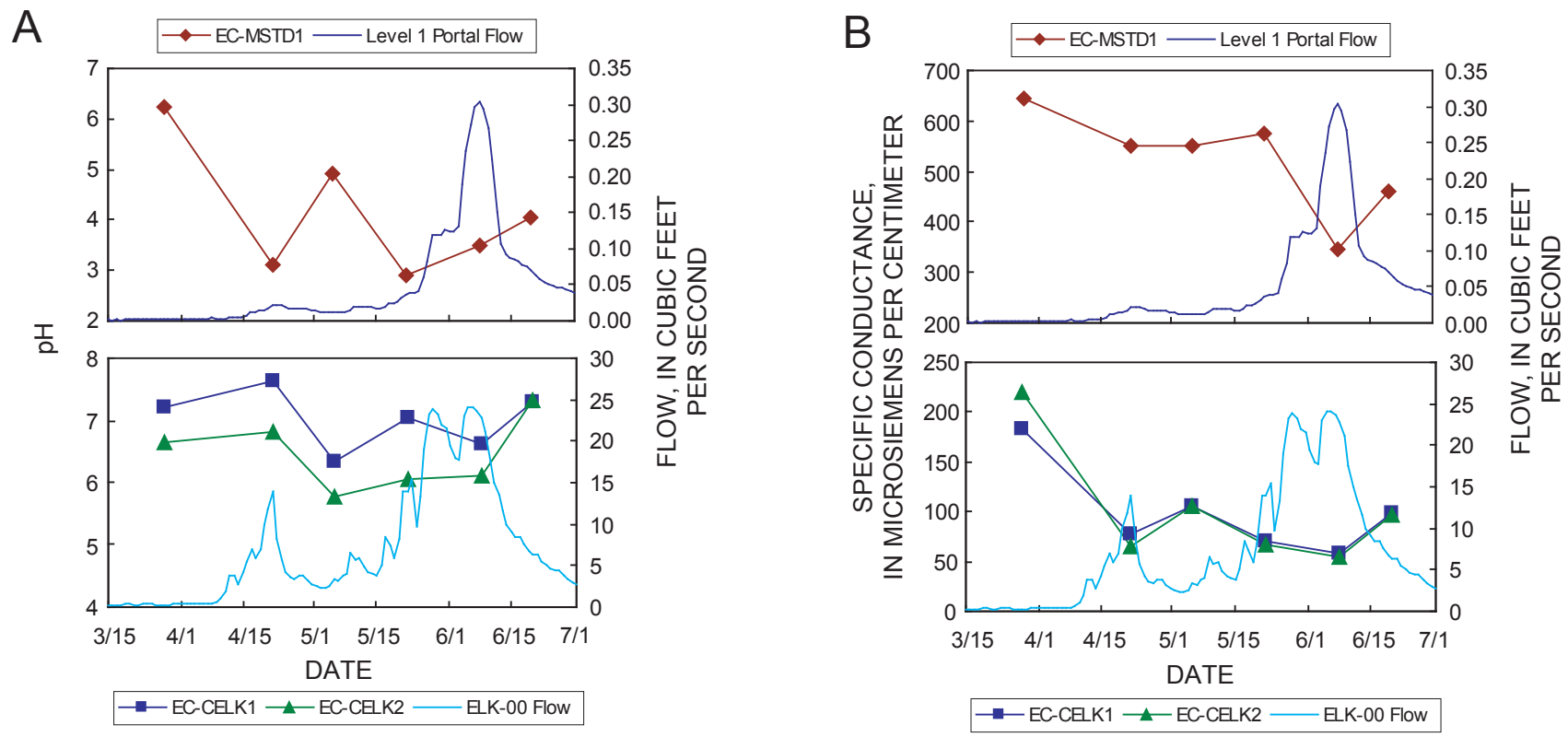

Figure 9. $\mathrm{pH}(\mathrm{A})$ and specific conductance (B) plotted versus sample date. Flows at the Level 1 portal the ELK-00 gage are shown for reference.
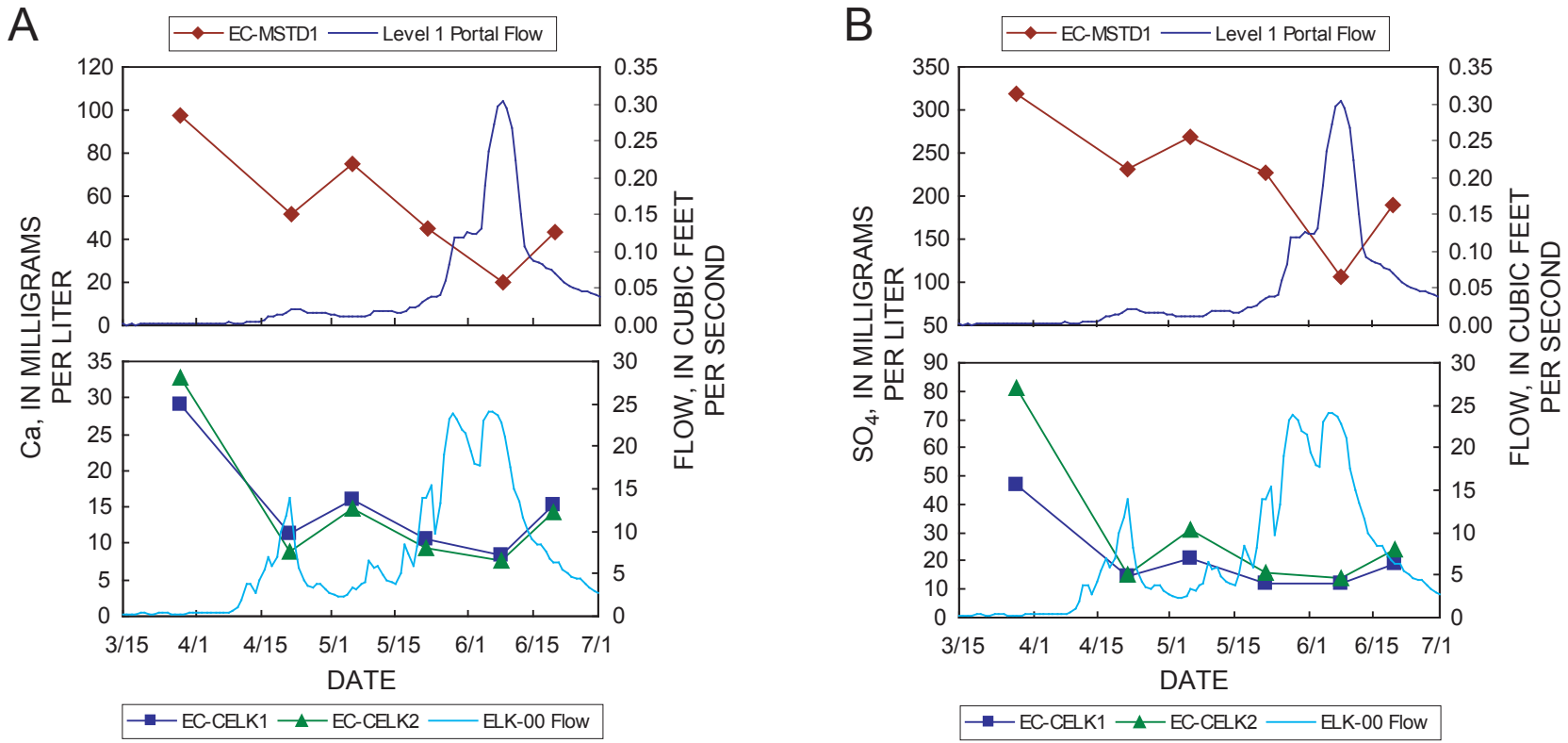

Figure 10. Calcium (A) and sulfate (B) concentration plotted versus sample date. Flows at the Level 1 portal the ELK-00 gage are shown for reference. 
A

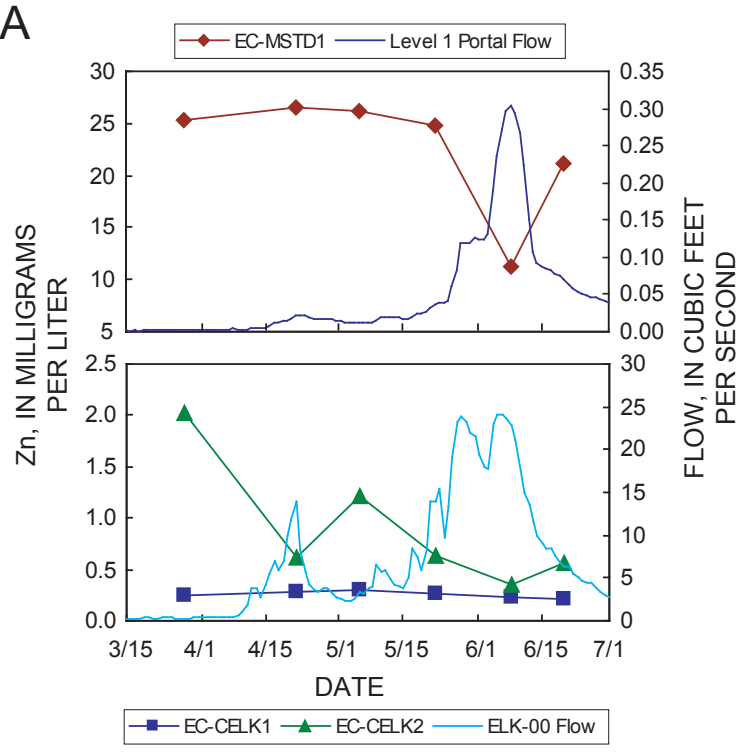

B
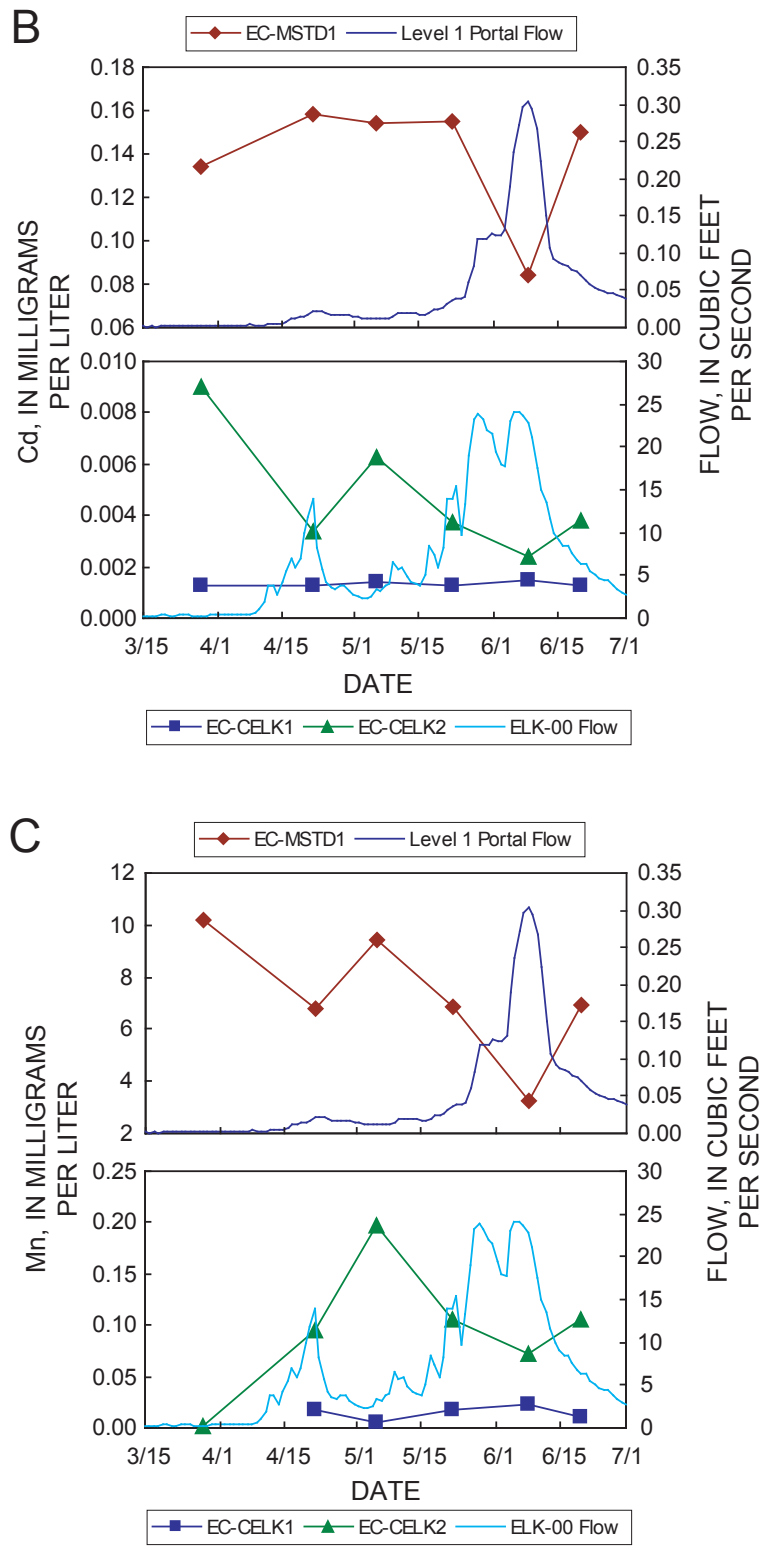
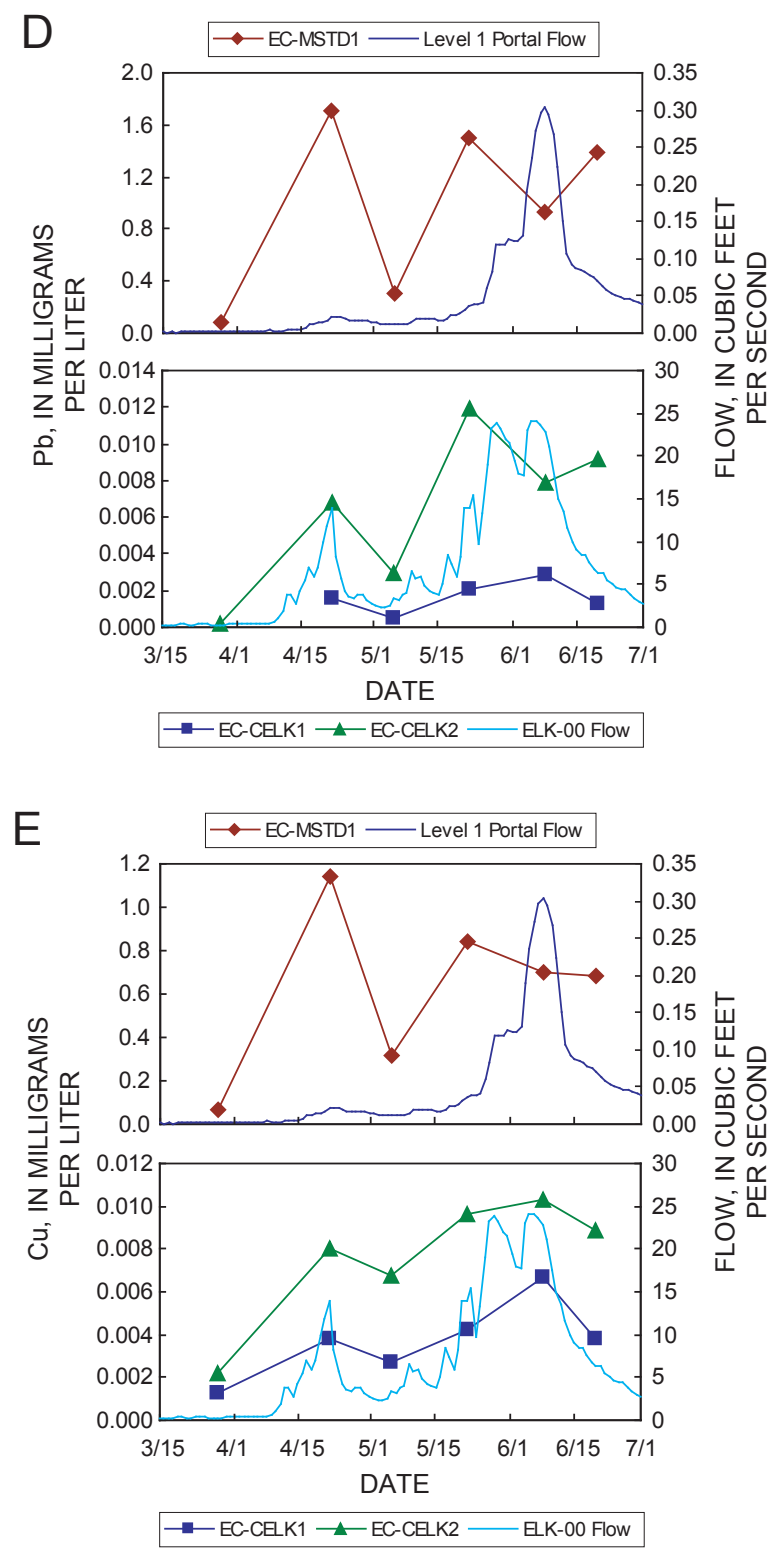

Figure 11. Zinc (A), cadmium (B), manganese (C), lead (D), and copper (E) concentration plotted versus sample date. Only samples with concentrations above detection limit are shown. Flows at the Level 1 portal the ELK-00 gage are shown for reference. 
Elk Creek, and vice versa (Mn excepted). The availability of continuous flow data at both the Level 1 portal and ELK-00 for the spring of 2010 allows for a more rigorous evaluation of this hypothesis by examining metal loads. Loads were computed for EC-MSTD1 and EC-CELK1 for each of the six sampling times using dissolved metal concentrations along with flows from the Level 1 portal gage and ELK-00 gage (located several hundred feet downstream from EC-CELK1) recorded within 15 minutes of the sampling time. If the Level 1 portal is the primary metal source to Elk Creek, metal loads at EC-CELK1 should be similar to or less than loads at ECMSTD1. Metal loads for the two sample sites are compared in figure 12. For the more conservative metals $\mathrm{Zn}$ and $\mathrm{Cd}$ (not

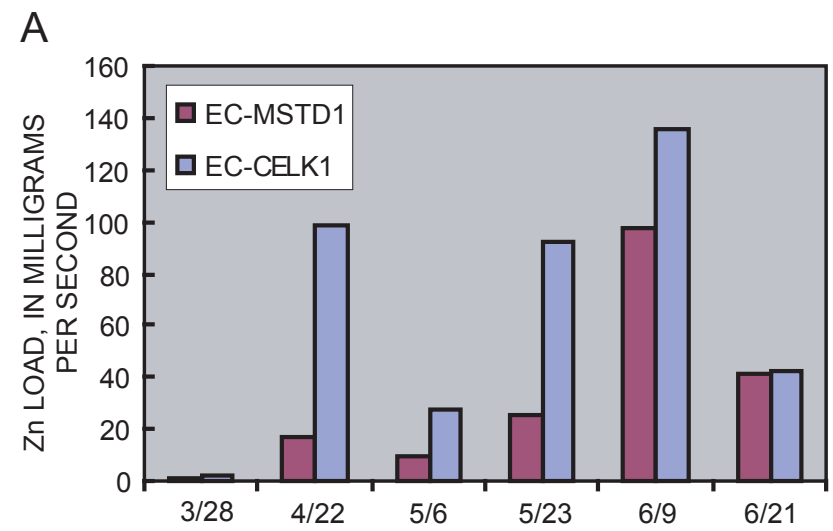

B
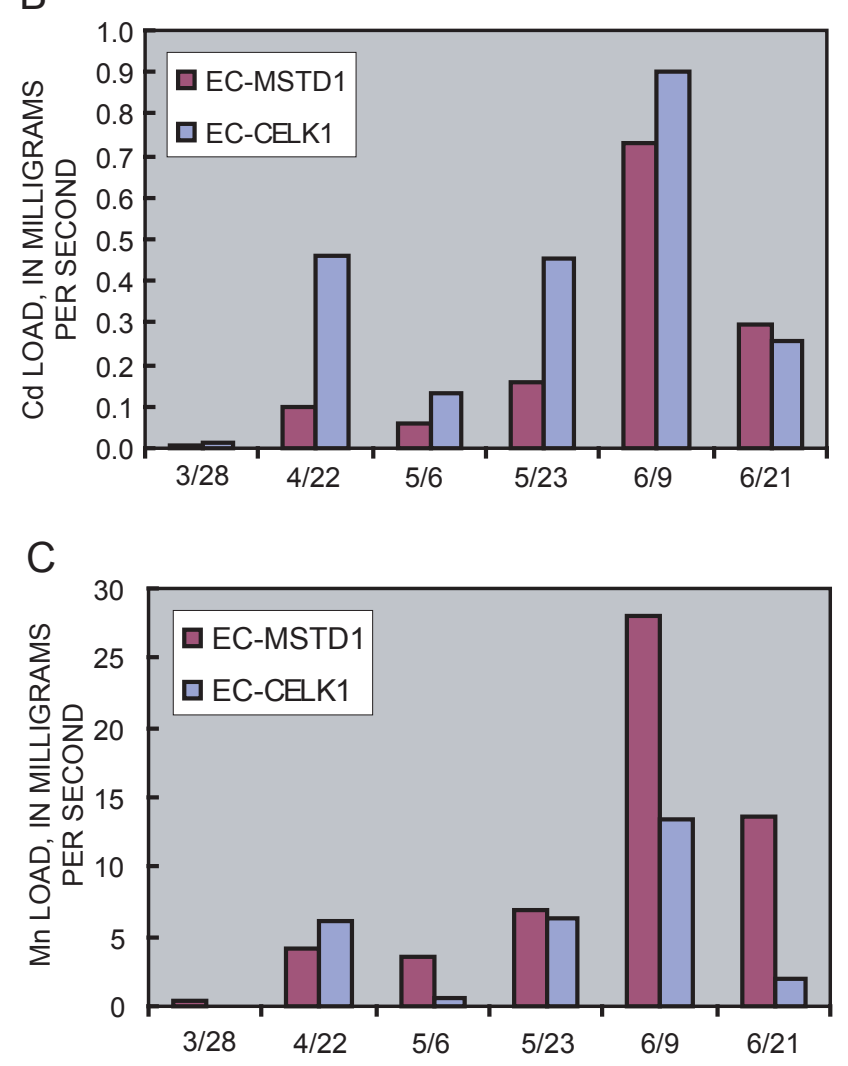

pH-sensitive), loads at EC-CELK1 are greater than at ECMSTD1 for five of the six sampling events. For $\mathrm{Mn}, \mathrm{Pb}$, and $\mathrm{Cu}$, loads at EC-CELK1 are generally less than at EC-MSTD1. However, these metals are $\mathrm{pH}$-sensitive so this could be due to $\mathrm{pH}$ differences at the two sites ( $\mathrm{pH} \geq 6$ at EC-ELK1 versus $\mathrm{pH}$ 3-5 at EC-MSTD1). The load results thus suggest that metals in Elk Creek during spring runoff may have sources other than the Level 1 portal. Discrepancies between $\mathrm{Zn}$ and $\mathrm{Cd}$ loads at the two sites generally decrease throughout the spring. This trend is consistent with the additional metal source(s) being located lower in the watershed, given that snowmelt sourced at lower elevation should compose a progressively smaller fraction of streamflow through the runoff period.
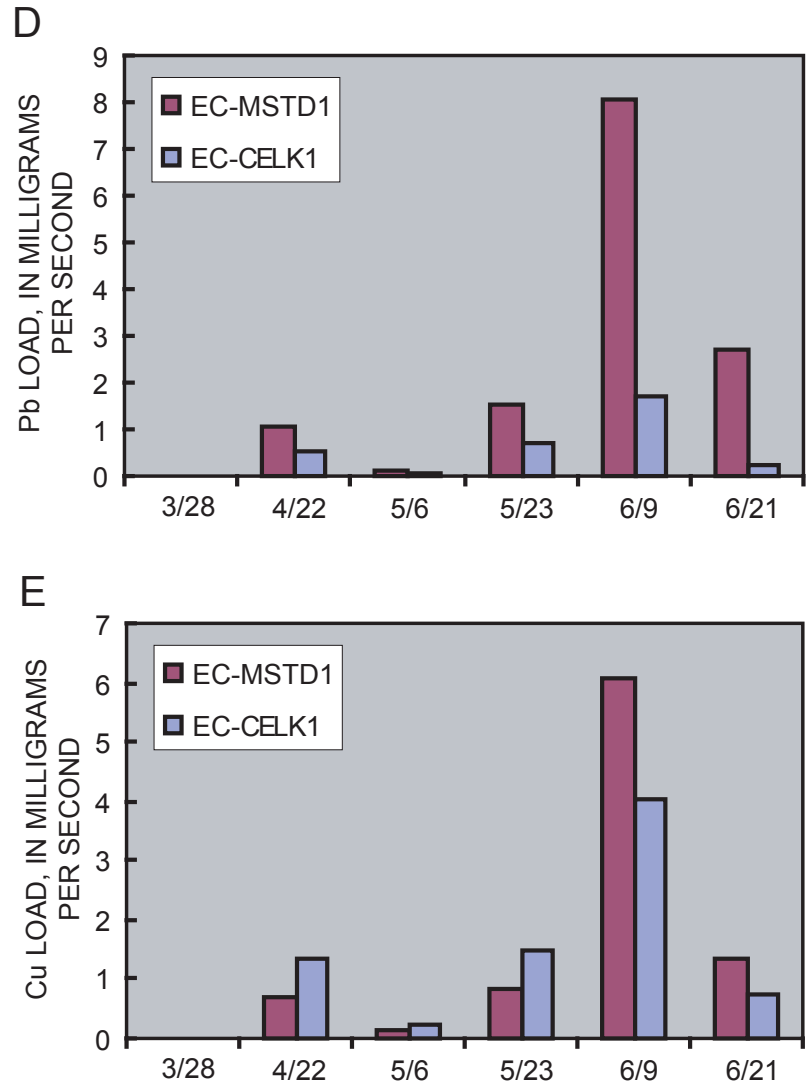

Figure 12. Bar charts showing calculated loads for zinc (A), cadmium (B), manganese (C), lead (D), and copper (E). Loads were computed for sampling sites EC-CELK1 and EC-MSTD1 for each sampling event. 
Two potential sources of error in the calculated loads include (1) the assumption that loads remained constant throughout the sample day (that is, neglecting possible diurnal variations in load), and (2) errors in the flow measurements. Samples were collected within about four hours of each other for each sampling event, and collected in downstream order (EC-MSTD1 first, EC-CELK1 last), minimizing the possibility of large errors due to diurnal load variations. The magnitude of the flow measurement uncertainty is unknown and may be large, but probably not large enough to completely account for observed differences in $\mathrm{Zn}$ and $\mathrm{Cd}$ loads between the two sites. Nonetheless, all calculated loads should be interpreted with some caution.

Calculated loads can also be used to evaluate the possibility discussed above that lower metal concentrations at EC-CELK1 in 2010 compared to 2007 are due simply to higher flows in Elk Creek in 2010, leading to greater dilution of portal discharge (assumed metal source). If this were the case, loads at EC-CELK1 would be similar to or greater than loads at EC-MSTD1. If not (i.e., if metals are being removed from portal discharge in the bioreactor), then loads at EC-CELK1 would be smaller. As previously discussed, loads for the conservative metals $\mathrm{Zn}$ and $\mathrm{Cd}$ at EC-CELK1 are generally greater than loads at EC-MSTD1, suggesting that dilution alone could indeed explain the lower $\mathrm{Zn}$ and $\mathrm{Cd}$ concentrations in 2010. It is possible that the bioreactor has a larger affect on the $\mathrm{Mn}, \mathrm{Pb}$, and $\mathrm{Cu}$ because loads of these metals at EC-CELK1 are similar to or less than EC-MSTD1. However, as mentioned above, this also simply could be a $\mathrm{pH}$ effect.

\section{Oxygen-18 and Deuterium}

Oxygen-18 and deuterium isotopic ratios $\left(\delta^{18} \mathrm{O}\right.$ and $\left.\delta^{2} \mathrm{H}\right)$ are presented in table 5 . Figure 13 shows temporal trends in $\delta^{18} \mathrm{O}$ and $\delta^{2} \mathrm{H}$ at the three sites sampled in 2010, as well as 2007 results and flow records for the Level 1 portal and ELK00 for reference. Discussion of these data focuses on $\delta^{18} \mathrm{O}$ because $\delta^{2} \mathrm{H}$ displays very similar trends to $\delta^{18} \mathrm{O}$ for the 2010 samples, as expected. In 2007, $\delta^{2} \mathrm{H}$ showed some differences from $\delta^{18} \mathrm{O}$, but the reason for these is not clear and discussion of them is beyond the scope of this report. $2010 \delta^{18} \mathrm{O}$ values generally become lighter (more negative) during spring high flows, following a trend that is very similar to the dilutioncontrolled trends displayed by $\mathrm{SC}, \mathrm{Ca}$, and $\mathrm{SO}_{4}$ (figs. 9 and 10). 2007 samples follow the same first-order trend. This is likely due to precipitation $\delta^{18} \mathrm{O}$ values being generally heavier (less negative) in rain than in snow (Manning and others, 2008). In early spring immediately before snowmelt, baseflow waters in Elk Creek and in Level 1 portal discharge are likely composed of a mixture of prior precipitation - that is, both rain and snow. During spring runoff, the fraction of snowmelt (from the current year) in high flow waters is much larger, making $\delta^{18} \mathrm{O}$ values lighter.

A notable difference between the 2010 and $2007 \delta^{18} \mathrm{O}$ data is that 2010 values are lighter by 0.5 to 2 permil. This could be the result of annual variability in the isotopic composition of the snowpack caused by annual variability in dominant winter storm tracks. Another possible explanation is that the ratio of the current year's SWE to the prior summer's rain is larger for 2010 than 2007 according to measurements at the Schofield Pass SNOTEL site. For spring 2007, total SWE was 29 inches and the prior summer's rain totaled 15 inches resulting in a SWE/rain ratio of 1.9. For spring 2010, total SWE was 37 inches and the prior summer's rain totaled 8 inches resulting in a SWE/rain ratio of 4.6. Assuming that the prior summer's rain is a major control on $\delta^{18} \mathrm{O}$ values in the following baseflow period (more rain equals heavier), then the larger SWE/rain ratio for the spring of 2010 should result in lighter high-flow $\delta^{18} \mathrm{O}$ values, as observed. Another difference between 2010 and 2007 results is that $2007 \delta^{18} \mathrm{O}$ values at EC-MSTD1 increased early in the runoff period before decreasing later during the highest flows. An explanation for this is not clear, but it also may be related to differences in fractions and/or timing of prior years' rain and snow.

Table 5. Oxygen-18 and deuterium results.

[R (appended to sample name), replicate sample]

\begin{tabular}{llll}
\hline \multicolumn{1}{c}{ Sample Name } & $\begin{array}{c}\text { Sample } \\
\text { Date }\end{array}$ & $\begin{array}{c}\text { d180 } \\
\text { (permil) }\end{array}$ & $\begin{array}{c}\text { d2H } \\
\text { (permil) }\end{array}$ \\
\hline EC-CELK1-10 & $3 / 28 / 10$ & -16.88 & -123.7 \\
EC-CELK1-11 & $4 / 22 / 10$ & -18.00 & -129.4 \\
EC-CELK1-12 & $5 / 6 / 10$ & -18.00 & -128.4 \\
EC-CELK1-13 & $5 / 23 / 10$ & -18.15 & -131.0 \\
EC-CELK1-14 & $6 / 9 / 10$ & -17.45 & -130.1 \\
EC-CELK1-15 & $6 / 21 / 10$ & -16.98 & -124.9 \\
EC-CELK2-01 & $3 / 28 / 10$ & -16.62 & -121.8 \\
EC-CELK2-02 & $4 / 22 / 10$ & -17.70 & -128.4 \\
EC-CELK2-03 & $5 / 6 / 10$ & -17.40 & -126.4 \\
EC-CELK2-04 & $5 / 23 / 10$ & -18.00 & -131.4 \\
EC-CELK2-05 & $6 / 9 / 10$ & -17.74 & -130.0 \\
EC-CELK2-06 & $6 / 21 / 10$ & -17.10 & -125.8 \\
EC-MSTD1-11 & $3 / 28 / 10$ & -16.58 & -119.2 \\
EC-MSTD1-12 & $4 / 22 / 10$ & -16.94 & -122.7 \\
EC-MSTD1-13 & $5 / 6 / 10$ & -16.75 & -121.9 \\
EC-MSTD1-14 & $5 / 23 / 10$ & -17.35 & -124.2 \\
EC-MSTD1-15 & $6 / 9 / 10$ & -17.84 & -129.6 \\
EC-MSTD1-15R & $6 / 9 / 10$ & -17.92 & -129.2 \\
EC-MSTD1-16 & $6 / 21 / 10$ & -17.22 & -124.8 \\
\hline & & &
\end{tabular}


A

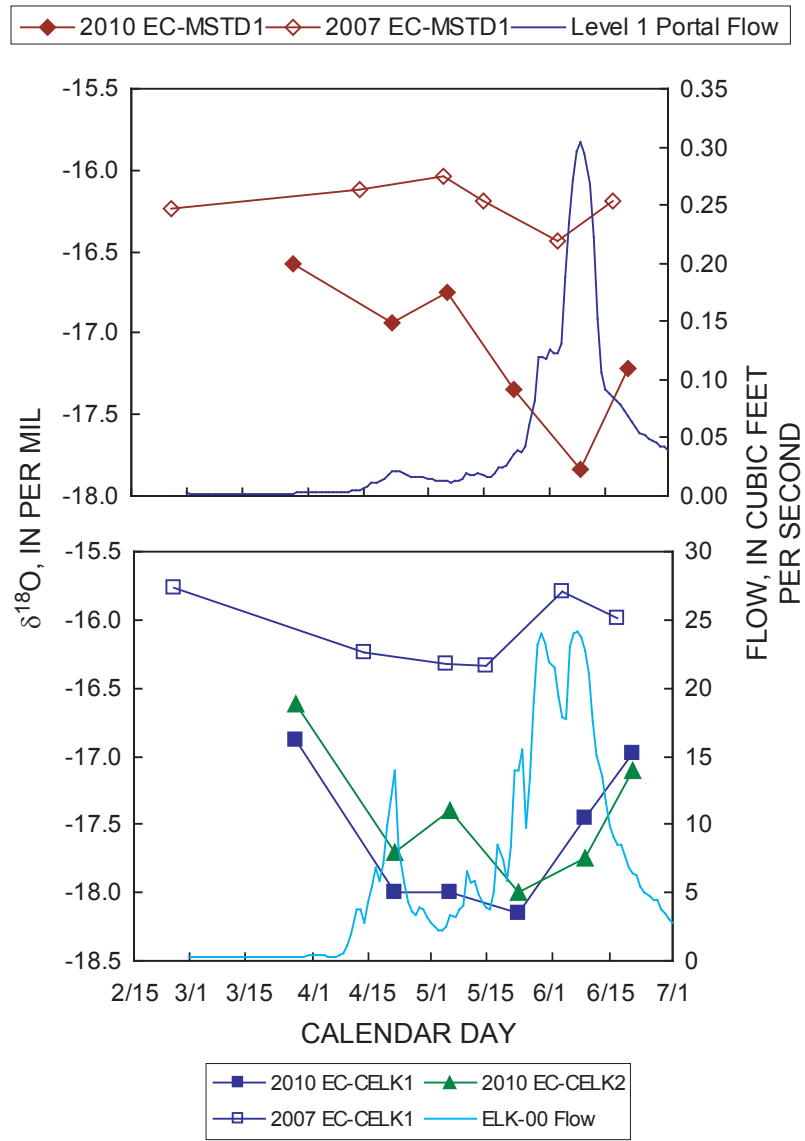

B

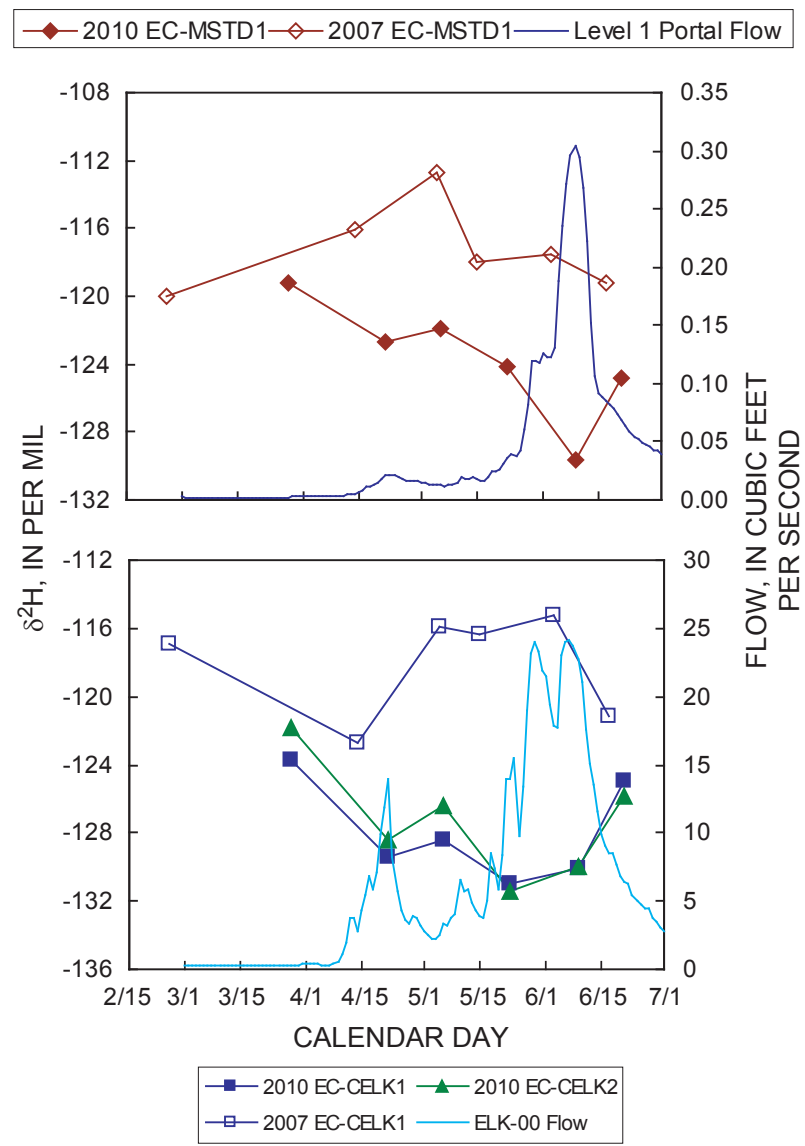

Figured 13. $\delta^{18} \mathrm{O}(\mathrm{A})$ and $\delta^{2} \mathrm{H}(\mathrm{B})$ values plotted versus calendar day of sample collection. 2007 results at EC-MSTD1 and EC-CELK1, along with 2010 flows at the Level 1 portal the ELK-00 gage, are shown for reference. 


\section{Conclusions}

1. Field parameter values ( $\mathrm{pH}$ and specific conductance), major ion concentrations (calcium and sulfate), and metal concentrations (zinc, cadmium, manganese, lead, and copper) in Level 1 portal discharge are similar to those in 2007 reported by Manning and others (2008). For samples collected at sample site EC-CELK1 near the mouth of Elk Creek, field parameter values and major ion concentrations measured in 2010 and 2007 are similar, but 2010 metal concentrations are lower. These lower concentrations could be due either to remedial activities performed at the Standard Mine site between 2007 and 2010, or to greater dilution of Level 1 portal discharge in 2010 caused by higher Elk Creek flows.

2. Temporal patterns in field parameters, major ion concentrations, and metal concentrations during the 2010 spring runoff period were similar to those in 2007 reported by Manning and others (2008). The $\mathrm{pH}$, specific conductance, and major ion concentrations generally decreased during high flows. The $\mathrm{pH}$ of Level 1 portal discharge dropped from about 6 to about 3 in the early stages of snowmelt. Concentrations of zinc, cadmium, and manganese generally decreased during high flows and concentrations of lead and copper generally increased.

3. The 2010 data support the finding by Manning and others (2008) that two primary factors control metal concentrations in Level 1 portal discharge and Elk Creek: dilution and $\mathrm{pH}$. Zinc and cadmium concentrations are apparently dilution-controlled, being inversely proportional to streamflows. Lead and copper concentrations are apparently $\mathrm{pH}-$ controlled, being inversely proportional to $\mathrm{pH}$ and poorly correlated with streamflows. Manganese concentrations may be either dilution-controlled or $\mathrm{pH}$-controlled, depending on sample location and time within the runoff period.

4. Calculated zinc and cadmium loads near the mouth of Elk Creek (EC-CELK1) are generally greater than loads at the Level 1 portal. This suggests that another source of zinc and cadmium in addition to the Level 1 portal might exist for Elk Creek during the spring runoff period. This also suggests that the lower metal concentrations measured near the mouth of Elk Creek (EC-CELK1) in 2010 compared to 2007 could be explained solely by greater dilution in 201 However, uncertainties in the calculated loads are not well characterized and could be substantial.

5. $\delta^{18} \mathrm{O}$ values are well correlated with flow, becoming lighter (more negative) during spring high flows in both Level 1 discharge and Elk Creek. The distinct seasonal drop in $\delta^{18} \mathrm{O}$ in Level 1 discharge, along with portal flow tracking very closely with creek flow, is consistent with geochemical and environmental tracer data collected by Manning and others (2008) indicating short residence times ( $<1$ year) for groundwater discharging from the Standard Mine.

\section{References Cited}

Ball, J.W., and Nordstrom, D.K., 1991, User's manual for WATEQ4F, with revised thermodynamic data base and test cases for calculating speciation of major, trace, and redox elements in natural waters: U.S. Geological Survey OpenFile Report 91-183, 189 p.

Barringer, J.L., and Johnsson, P.A., 1989, Theoretical considerations and a simple method for measuring alkalinity and acidity in low-pH waters by gran titration: U.S. Geological Survey Water-Resources Investigations Report 89-4029, $35 \mathrm{p}$.

Brinton, T.I., Antweiler, R.C., and Taylor, H.E., 1995, Method for the determination of dissolved chloride, nitrate and sulfate in natural water using ion chromatography: U.S. Geological Survey Open-File Report 95-426, 16 p.

Caine, J.S., Manning, A.H., Berger, B.R., Kremer, Y., Guzman, M.A., Eberl. D.D., and Schuller, K., 2010, Characterization of geologic structures and host rock properties relevant to the hydrogeology of the Standard Mine in Elk Basin, Gunnison County, Colorado: U.S. Geological Survey Open-File Report 2010-1008, 55 p.

Colorado Division of Reclamation, Mining, and Safety, 2007, Draft underground assessment, Standard Mine Superfund site, Gunnison County, Colorado: Denver, Colorado, 37 p.

Dzombak, D.A., Morel, F.M., 1990, Surface Complexation Modeling - Hydrous Ferric Oxide: New York, John Wiley and Sons, $393 \mathrm{p}$.

Epstein, Samuel, and Mayeda, T., 1953, Variation of ${ }^{18} \mathrm{O}$ content of waters from natural sources: Geochimica et Cosmochimica Acta, v. 4, p. 213-224.

Kendall, Carol, and Coplen, T.B., 1985, Multisample conversion of water to hydrogen by zinc for stable isotope determination: Analytical Chemistry, v. 57, p. 1437-1440.

Kuehner, E.C., Alvarez, R., Paulsen, P.J., and Murphy, T.J., 1972, Production and analysis of special high-purity acids purified by sub-boiling distillation: Analytical Chemistry, v. 44, p. 2050-2056.

Lamothe, P.J., Meier, A.L., and Wilson, S.A., 2002, The determination of forty-four elements in aqueous samples by inductively coupled plasma-mass spectrometry, in Taggart, J.E., Jr., ed., Analytical methods for chemical analysis of geologic and other materials, U.S. Geological Survey: U.S. Geological Survey Open-File Report 02-223, chapt. H, 13 p.

Manning, A.H., Verplanck, P.L., Mast, M.A., and Wanty, R.B., 2008, Hydrogeochemical investigation of the Standard Mine vicinity, upper Elk Creek Basin, Colorado: U.S. Geological Survey Scientific Investigations Report 2007-5265, $131 \mathrm{p}$. 
Meier, A.L., Grimes, D.J., and Ficklin, W.H., 1994, Inductively coupled plasma-mass spectrometry-A powerful analytical tool for mineral resource and environmental studies [abs], in Carter, L.M.H., Toth, M.I., and Day, W.C., eds., U.S. Geological Survey Research on Mineral Resources-1994, Part A-Program and abstracts, ninth V.E. McKelvey Forum on mineral and energy resources: U.S. Geological Survey Circular 1103-A, p. 67-68.

Minsley, B.J., Ball, L.B., Burton, B.L., Caine, J.S., CurryElrod, E., and Manning, A.H., 2010, Geophysical characterization of subsurface properties relevant to the hydrology of the Standard Mine in Elk Basin, Colorado: U.S. Geological Survey Open-File Report 2009-1284, 41 p.

Sharp, J.E., 1978, A molybdenum mineralized breccia pipe complex, Redwell Basin, Colorado: Economic Geology, v. 73, p. 369-382.

Stookey, L. L., 1970, FerroZine-a new spectrophotometric reagent for iron: Analytical Chemistry, v. 42, p. 779-781.

To, T.B., Nordstrom, D.K., Cunningham, K.M., Ball, J.W., and McCleskey, R.B., 1999, New method for direct determination of dissolved $\mathrm{Fe}(\mathrm{III})$ concentrations in acid mine waters: Environmental Science and Technology, v. 33, p. 807-813.

URS Operating Services, Inc. (UOS), 2010, Final Remedial Investigation Report, Standard Mine, Gunnison County, Colorado: Denver, Colorado, 235 p.

Verplanck, P.L., Manning, A.H., Mast, M. A., Wanty, R.B., McCleskey, R.B., Todorov, Todor, and Adams, Monique, 2007, Selected water-quality data for the Standard Mine, Gunnison County, Colorado, 2006-2007: U.S. Geological Survey Open-File Report 2007-1241, 12 p.

Verplanck, P.L., Manning, A.H., Graves, J.T., McCleskey, R.B., Todorov, Todor, and Lamothe, P.J., 2010, Geochemistry of Standard Mine waters, Gunnison County, Colorado, July 2009: U.S. Geological Survey Open-File Report 2009$1292,21 \mathrm{p}$.

Wood, R.H., II, and Oerter, E.J., 2007, History, geology, and environmental setting of the Micawber mine and elk load in the Ruby Mining District, Gunnison National Forest, Gunnison County, Colorado: Colorado Geological Survey Open-File Report 08-10, 85 p. 


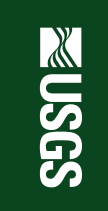

省

플 